\title{
Bank risk and performance in the MENA region: \\ The importance of capital requirements ${ }^{1}$
}

\author{
Mohammad Bitar ${ }^{\mathrm{a}^{*}}$, Wadad Saad $^{\mathrm{b}}$, Mohammed Benlemlih $^{\mathrm{c}}$
}

\author{
${ }^{a *}$ Corresponding author. Tel.: +1 514627 9344; Fax: +1 5148484500 \\ David O'Brien Centre for Sustainable Enterprise, Concordia University, 1455 Blvd. de Maisonneuve \\ West, Montréal, Canada. \\ E-mail address: mohammad.bitar@ concordia.ca. \\ ${ }^{b}$ Lebanese University, Faculty of Business Administration and Economics, Beirut, Lebanon. \\ E-mail address: wsaad@ul.edu.lb. Tel.: +961 3880036 \\ ${ }^{c}$ University of Grenoble Alps, Grenoble, France. \\ E-mail address: mohammad.benlemlih@upmf-grenoble.fr. Tel.: +33649817510
}

\begin{abstract}
This paper benefits from various risk- and non-risk-based regulatory capital ratios and examines their impact on bank risk and performance in the Middle East and North Africa (MENA) region. Our findings suggest that compliance with Basel capital requirements enhances bank protection against risk, and improves efficiency and profitability. The impact of capital requirements on bank performance is more pronounced for too-big-to-fail banks, banks in periods of crises and banks in countries with good governance. The results are also robust when controlling for the Arab Spring transition period. Finally, endogeneity checks, alternative risk and performance measures, a principal component analysis and other estimation techniques confirm findings.

JEL classification: G21, G28, G32, P5.
\end{abstract}

Keywords: Basel capital, too-big-to-fail, Arab Spring, risk, efficiency, profitability.

\footnotetext{
${ }^{1}$ Mohammad Bitar and Wadad Saad gratefully acknowledge the financial support provided by the Lebanese University, Lebanon.
} 


\section{Introduction}

Investigations into whether bank capital has a positive or negative effect on bank risk and performance proliferated after the 2007/2008 subprime crisis. Existing empirical work mainly focuses on the association between capital, risk and profitability in American and European contexts (Altunbas et al., 2007; Demirgüç-Kunt et al., 2013). However, recent research brings novel insights into banks in alternative regions or countries: the Asian (Lee and Hsieh (2013)), the Sub-Saharan African (Flamini et al., 2009), the Middle Eastern and North African (MENA) regions (Ben Naceur and Omran, 2011), and banks in Egypt (Ben Naceur and Goaied, 2008) and Tunisia (Ben Naceur and Kandil, 2009). Despite the ongoing debate on the importance of financial reforms, there are no empirical studies that examine the impact of banking regulation (in particular, capital requirements in light of the Basel accords) on the risk and the performance of banks in the MENA region. Accordingly, this paper examines the impact of Basel capital requirements on risk and bank performance (namely efficiency and profitability) for a sample of 168 banks in 17 Middle Eastern and North African countries for the 1999-2013 period.

Our study differs because we extend the analysis to examine the effect of bank capital on risk, efficiency and profitability using risk-based regulatory ratios and non-risk-based traditional capital ratios. Evidence of the impact of Basel capital requirements (namely, Tier 1 capital, Tier 2 capital and total capital ratio) on bank risk and performance in the MENA region is scarce. In addition, as far as we know, no existing studies have employed both the Basel risk-based capital ratios and the traditional non-risk-based capital ratios (such as common equity and tangible equity) to investigate their impact on both bank risk and performance.

We investigate the MENA countries for several reasons. First of all, the credit growth in the MENA region has been more moderate, less volatile and less risky. However, more recently, MENA countries have experienced rapid and more volatile credit growth rates, which may raise concerns about the stability of the financial system, and especially that higher credit growth is often followed by financial crisis (Crowley, 2008). Second, the MENA 
region contains four of the most essential and international trade canals or checkpoints (Suez, Hormuz, Bab-el-Mandeb and Gibraltar). Third, as a bridge between developed and developing countries in Europe, Asia and Africa, the MENA region attracts investors and bankers worldwide. This strategic position makes the MENA countries more susceptible to political instability and thus economic and financial vulnerability. In addition, the region is facing numerous changes such as the opening up of certain markets to foreign competition, the expansion of the private sector and the increased role of bank lending. In practice, several countries in the MENA region have adopted financial reforms since the late 1990s for the purpose of ensuring efficiency in allocating bank resources and enhancing productivity. Yet, this region is still ranked far behind the industrialized countries (Creane et al., 2004). Therefore there is a need to strengthen banking supervision and regulation by conforming to international Basel standards, especially the capital requirements.

We find that higher risk- and non-risk-based capital ratios are positively associated with bank loan loss reserve ratios, bank efficiency and profitability, consistent with the recommendations of the Basel Committee on Banking and Supervision (BCBS) regarding the importance of holding higher capital ratios. Our results also show that banks in the MENA region are less capable of dealing with capital-like ratios (that is, Tier 2 ratios) than those in GCC countries. In particular, the latter benefit from the oil boom, expertise and connections with many Western banks operating in the Gulf region. Accordingly, banks are encouraged to increase the Tier 1 element in their capital adequacy ratios rather than the Tier 2 element. Moreover, the impact of capital requirements on bank efficiency and profitability is more effective for too-big-to-fail banks, banks in countries with a good governance policy and banks during the Arab Spring political transition period. In addition, we find differences in the effect of capital ratios when comparing banks in GCC countries with banks in the rest of the MENA region and banks during crisis with banks during normal times, especially for capitallike ratios. This provides additional support to the importance of capital guidelines and good governance in preventing financial instability in periods of political transition and financial distress. Finally, an instrumental variables approach, alternative risk and performance 
measures, a principal component analysis and other estimation techniques validate our findings.

Our research contributes to the existing literature in several ways. For the first time, we examine the impact of the Basel guidelines - in terms of risk- and non-risk-based regulatory capital requirements - on the risk, efficiency and profitability of commercial banks in the MENA region. Also, our study is different because we use eight capital ratios and combine risk-based capital measures with non-risk-based capital measures to compare and examine whether the Basel Accords have a pronounced effect on the bank risk and performance of a large sample of commercial banks in the MENA region. We use risk- and non-risk-based capital ratios because of the renewed debate on the effectiveness of capital requirements. For instance, Demirgüç-Kunt et al. (2013) and Anginer and Demirgüç-Kunt (2014) ask what kind of capital banks need to use and how to structure it. This is consistent with Haldane (2012), Dermine (2015) and Cathcart et al. (2015) who shed doubts on the ability of risk-weighted assets to reflect actual bank risk exposure, especially during the subprime crisis. This paper adds to the literature on the effectiveness of capital requirements (Basel risk-based capital ratios versus traditional non-risk-based capital ratios) by examining the banks in the MENA region. In the additional subsample comparison analyses between Gulf Cooperation Council (GCC) countries and the remaining MENA countries, we study the impact of the Arab Spring transition period on the linkage between capital, risk and bank performance in both regions. Furthermore, we not only consider the traditional relationship between capital and risk but also extend our study to examine banking efficiency and profitability. Finally, we utilize several regression techniques and combine parametric approaches (OLS regressions, 2SLS, LIML, GMM) and nonparametric approaches (principal component analysis and quantile regressions) to examine the robustness of our results.

This paper proceeds as follows: Section 2 establishes the theoretical and empirical frameworks by examining the relationships between bank capital, risk and performance. Section 3 describes the data and summarizes the variables' characteristics. Section 4 reports and discusses the empirical results. The last section discusses the paper's limitations and implications for regulators and policymakers in the MENA region. 


\section{Literature review}

VanHoose (2007) provides an extensive literature review of the impact of capital requirements on the stability (risk) of the banking system. However, only a limited number of studies extend this association to examine bank efficiency and profitability for the European context (Altunbas et al., 2007) and for the Asian context (Lee and Hsieh, 2013). In contrast to most previous research, our study uses various types of capital to examine, for the first time, their effect on the risk, efficiency and profitability of banks in the MENA region. Below is a review of the literature on bank capital, risk, efficiency and profitability.

\subsection{Risk and capital requirements}

Lee and Hsieh (2013) argue that the relationship between capital and risk can be explained by using the regulatory and moral hazard paradigms. They refer to the moral hazard hypothesis, in which capital has a negative impact on bank risk, and to the regulatory hypothesis, in which capital and risk are positively associated.

Generally, unregulated banks tend to take excessive risks to maximize the shareholder value at the expense of the depositors. In fact, the reason behind this is that if high-risk loans do not pay off, depositors' money is protected by deposit insurance (Furlong and Keeley, 1989; Keeley and Furlong, 1991). In addition, the depositors lose interest in supervising the bank's investments because their money is guaranteed (Demirgüç-Kunt and Kane, 2001). As a result, deposit insurance is no longer effective in preventing bank runs ${ }^{2}$ (Bryant, 1980; Diamond and Dybvig, 1983). Paradoxically, this situation creates incentives for managers to take on more risk. To prevent this pattern of moral hazard and to support financial regulation theory, a capital risk plan must be integrated (Kim and Santomero, 1988). This plan refers to a positive relationship between capital and risk, meaning that supervisory authorities encourage banks to increase their capital commensurably with the amount of risk taken (Iannotta, 2006; Altunbas et al., 2007; Iannotta et al., 2007). As a result, banks will be more prudent with their choice of riskier activities to avoid costly increases in their capital ratio. Thus, the objective of

\footnotetext{
${ }^{2}$ Demirgüç-Kunt and Kane (2001) explain that to make deposit insurance a safety net for small depositors and a good way of reducing concerns about the stability of small banks, the supervisory authorities must be active and efficient.
} 
the capital adequacy ratio is to force banks to internalize their losses and decrease the moral hazard (Rime, 2001), namely by forcing the bank shareholders to absorb a large part of the losses (Anginer and Demirgüç-Kunt, 2014). Consequently, the quality of assets and offbalance sheet risk exposure will be integrated into the bank capital requirement, thereby strengthening the stability of the banking system (Barrios and Blanco, 2003; Vazquez and Federico, 2015).

Alternatively, some authors argue that there is a negative relationship between capital and risk (Jahankhani and Lynge, 1980; Brewer and Lee, 1986; Jacques and Nigro, 1997; Agusman et al., 2008). Berger and Bouwman (2013) examine US banks and find that capital has a positive impact on small banks' probability of survival during crisis periods. Anginer and Demirgüç-Kunt (2014) find a negative association between capital measures and several indicators of bank risk when examining an international sample. The same results are obtained by Klomp and de Haan (2014) when examining a sample of banks in 70 developing and emerging countries and Lee and Hsieh (2013) when studying banks in 42 Asian countries. Employing a legal quality index, Neyapti and Nergiz Deincer (2014) show that bank regulation and supervision - including capital requirements - reduce bank non-performing loans and help achieve a sustainable and efficient resource allocation of bank depositors' savings into investments.

While the literature shows mixed results regarding the association between capital and risk, a new stream of research indicates that capital requirements (especially the Basel riskweighted assets capital ratio) have no significant impact on bank risk (Demirgüç-Kunt and Detragiache, 2011; Arnold et al., 2012; Haldane, 2012). This was reflected in the subprime crisis and raised doubts about the effectiveness of the risk-weighting methodology. Cathcart et al. (2015) report that the top 25 banks in the United States and Europe had Tier 1 capital ratios of $8.3 \%$ and $8.1 \%$, which are much higher than the $4 \%$ of regulatory Tier 1 capital ratio required by the BCBS. However, despite the high level of solvency ratios, these banks were not able to absorb their risk exposure and prevent systemic risk. Arnold et al. (2012) argue that regulators need to distinguish between capital of good quality (for example, the common equity Tier 1 capital ratio) and capital-like ratios (for example, debt ratios or Tier 2 capital 
ratio). They explain that while more capital is good, it is important to understand that some capital is better than other capital. In the same context, Dermine (2015) criticizes the Basel II/III capital ratio and focuses on capital's denominator risk-weighting methodology. The study shows that the only way to prevent any untruthful bank risk exposure is to create a complementary non-risk-based leverage ratio that serves in addition to the capital regulatory ratio (Blum, 2008; Arnold et al., 2012; Haldane, 2012). The BCBS adopted this concept in 2014 (BCBS, 2014) and public disclosure of the leverage ratio was available from January 1, 2015.

\subsection{Efficiency, profitability and capital requirements}

Lee and Hsieh (2013) find that the association between capital and risk depends on the level of bank profitability. The two authors examine a sample of Asian banks and find that capital has a positive effect on bank profitability but a negative effect on bank risk. Altunbas et al. (2007) study the European banking system and find a positive association between capital and risk, and a negative association between capital and efficiency. These two studies are examples of the mixed literature about the relationship between capital requirements and bank risk and performance (profitability and efficiency).

Examining a sample of 181 large banks from 15 European countries, Iannotta et al. (2007) find a positive and significant association between capital and two indicators of bank profitability and a negative and significant association between capital and bank cost. The authors offer three explanations for their results. First, higher bank capitalization may be reflected in higher management quality and thus higher income and lower cost, which generate more bank profits. Second, capitalized banks are most likely to have lower bankruptcy costs, which in turn reduce funding costs, thereby generating higher income. Berger (1995) reaches a similar conclusion. Employing a Granger causality test, the author studies the causality relationship between capital and earnings measured by return on equity. His results suggest a positive effect of capital on bank earnings. Berger's results and explanations are in line with those of Demirgüç-Kunt and Huizinga (2000), who also find a positive association between equity-to-assets and bank profits when examining a sample of 
banks in 44 developed and developing countries. Finally, Iannotta (2006) argues that according to the Basel guidelines, banks are required to increase their capital ratios commensurably with the amount of risk taken. Higher capital ratios diminish banks' leverage behavior and thus their expected returns. Fiordelisi et al. (2011) explain that lower returns induce bank owners to choose a higher point on the efficiency frontier to improve their profits. This leads to investments in riskier portfolios. As a consequence, a positive effect should be expected between capital and profits.

Working in the same context, Chortareasa et al. (2012) find that capital requirements have a positive effect on efficiency and a negative effect on bank costs when using an unbalanced panel of 5,227 bank-year observations in 22 European Union countries. The authors suggest that a higher level of capitalization reduces agency problems between managers and shareholders. Accordingly, the latter will have greater incentives to monitor management performance and ensure that the bank is efficient.

Demirgüç-Kunt et al. (2013) find that capital requirements had a positive influence on bank stock market returns in the 2007-2008 financial crisis. Their results are even stronger with larger banks. Accordingly, they support the hypothesis that higher capital ratios especially capital of good quality, such as Tier 1 capital or common equity - strengthen bank performance.

With regard to efficiency, the literature offers two types of measures: accounting ratios (such as cost-to-income ratio, net interest margin, operating income and profits) and efficiency scores computed using nonparametric approaches ${ }^{3}$ such as Data Envelopment Analysis (DEA). Below, we document the main references for the efficiency score literature.

Pasiouras (2008) investigates the impact of the regulation and supervision recommended by Basel II on bank efficiency and finds that efficiency scores increase with bank capitalization. Staub et al. (2010) test a moral hazard hypothesis and find that when

\footnotetext{
${ }^{3}$ Berger (1997, 2007) offers an extensive literature review on studies that use parametric and nonparametric approaches. The efficiency scores can be estimated using other nonparametric approaches such as the Free Disposal Hull (FDH). In addition to nonparametric approaches, efficiency scores can be computed using parametric approaches such as the stochastic frontier approach (SFA), the distribution-free approach (DFA) and the thick frontier approach (TFA).
} 
banks hold more capital they are more cautious in terms of their risk behavior, which can be channeled into higher efficiency scores. Banker et al. (2010) show that the capital ratio is positively correlated with several types of bank efficiency (aggregate efficiency, technical efficiency and allocative efficiency) when studying the efficiency scores of 14 Korean banks for the period 1995-2005. Sufian (2010) also highlights the important role of capital requirements in strengthening the capacity of financial institutions in the Chinese banking sector to withstand financial crises. Finally, Barth et al. (2013) study the relationship between banking regulations and efficiency. Their results suggest that capital stringency and equity-toasset ratios are positively associated with bank efficiency.

In this study, we benefit from the work of Anginer and Demirgüç-Kunt (2014) and explore whether different types (definitions) of capital ratios have the same impact not only on bank risk but also on bank efficiency and profitability.

\section{Data and methodology}

\subsection{Sample}

We use Bankscope as our primary source of data for this study (Demirgüç-Kunt et al., 2013; Lee and Hsieh, 2013; Anginer and Demirgüç-Kunt, 2014). For each bank in the sample, we retrieve annual data from 1999 to 2013 . The sample includes 168 banks from 17 MENA countries $^{4}$ (including six GCC countries). A bank is excluded from the sample if it does not have at least two continuous observations. In addition, we remove countries that have data for fewer than four banks. ${ }^{5}$ We finally note that our study tests and the significance of the results are limited by data availability.

\subsection{Measures of risk, efficiency and profitability}

The main objective of this paper is to examine the impact of various definitions of capital on bank risk and performance. We measure risk using the loan loss reserves to gross

\footnotetext{
${ }^{4}$ Specifically, our sample covers the following countries: Algeria, Bahrain, Egypt, Iraq, Jordan, Kuwait, Lebanon, Mauritania, Oman, the Palestinian territories, Qatar, Saudi Arabia, Sudan, Syria, Tunisia, Turkey, the UAE and Yemen.

${ }^{5} \mathrm{We}$ exclude Israel from the sample because it is considered to be a developed country.
} 
loans (LLRGLP). ${ }^{6}$ This ratio measures loan quality (Altunbas et al., 2007; Abedifar et al., 2013; Lee and Hsieh, 2013), with higher values indicating poorer loan quality or higher protection against credit default risk. For the robustness tests, we use nonperforming loans to gross loans (NPLGLP).

We measure performance using the bank cost-to-income ratio (CIRP). This ratio is used to control for any cross-bank differences in terms of efficiency; a higher value indicates a lower level of efficiency. In addition, we employ net income to total assets (EARTAP) as a measure of bank profitability (Demirgüç-Kunt et al., 2013; Anginer and Demirgüç-Kunt, 2014). For the robustness checks, we include the ratio of net interest margin (NIMP) and net income to gross loans (EARGLP). The former is computed as the bank [interest incomeinterest expenses] divided by the total earning assets (Chortareasa et al., 2012). The latter is another measure of bank profitability and performance.

\subsection{Measures of capital and control variables}

We follow the work of Demirgüç-Kunt et al. (2013) and Anginer and Demirgüç-Kunt (2014) and use several definitions of capital requirements. These measures are computed according to the Basel rule by using risk-weighted assets (rwa) in the first step. Then, in the second step, we compute the same ratios but we use total assets (ta) instead. The objective of such a comparison is to avoid any untruthful assessment related to the calculation of riskweighted assets (Arnold et al., 2012; Cathcart et al., 2015; Dermine, 2015). The first vector employs three ratios: Tier 1 (tier 1/rwa), Tier 2 (tier 2/rwa) and Tier 1 plus Tier 2 divided by risk-weighted assets and off-balance sheet exposures (total capital/rwa). Tier 1 capital is the sum of shareholders' funds and perpetual, noncumulative preference shares. Tier 2 capital is the sum of hybrid capital, subordinated debt, loan loss reserves and valuation reserves. Total capital, known as the capital adequacy ratio numerator, contains in addition to Tier 1 a

\footnotetext{
${ }^{6}$ We focus on credit risk for several reasons: First, credit risk is considered the most important type of risk a banking institution could face. It also constitutes, along with operational risk and market risk, the first pillar of Basel II. Second, due to limited data availability, we did not include market-based indicators such as the distance to default or other complex risk measures. Finally, stability indicators such as the Z-score cannot be used as a dependent variable because the Z-score already includes a capital measure, which could influence our regression results.
} 
proportion of Tier 2 capital. This ratio must be at least $8 \%$ under the Basel II rules. Bank common equity includes common shares, retained earnings, reserves for general banking risks and statutory reserves. Tangible common equity removes goodwill and any other intangible assets from its equity.

We also employ a series of bank-level control variables to capture the differences in bank characteristics. We first include the net loans to total assets (net loans/ta) as the literature shows that banks that possess an important loan portfolio are less exposed to risk than other banks that prefer to invest in derivatives, other types of securities and other nontraditional activities. Second, we use growth of total assets (growth assets) to control for the evolution of the bank's total assets for the current year compared with the previous year. Abedifar et al. (2013) qualifies this ratio as a proxy for bank growth and development strategy. Third, we check for diversification using the income diversity ratio (income diversity). This captures the degree to which banks diversify between lending and non-lending activities. Demirgüç-Kunt and Huizinga (2010) and Baele et al. (2007) find that greater reliance on noninterest income is linked to more volatile returns. Stiroh (2004) finds a negative association between total bank risk and diversification of revenue. We follow Laeven and Levine (2007) and compute income diversity as $1-[($ net interest income-other operating income)/(operating income)]. On average, income diversity takes values between 0 and 1 . The higher the value, the more activities are diversified. To control for risk and efficiency, we use the cost-to-income ratio in the risk model and loan loss reserves to total assets in the efficiency and profitability models. Finally, we use the natural logarithm of total assets to control for bank size (size). All the variables are winsorized at the $1 \%$ and $99 \%$ levels to mitigate the effect of outliers. The variable definitions and sources are explained in Appendix A.1.

\section{Empirical results}

In this section, we present the variables' descriptive statistics, main results and several other robustness techniques. 


\subsection{Descriptive statistics}

Table 1 presents the descriptive statistics of banks' variables of interest (namely, endogenous and exogenous) and control variables. ${ }^{7}$ The number of observations varies dramatically between risk-based capital measures and non-risk-based capital measures. For instance, Tier 1 capital to risk-weighted assets (Tier 1/rwa) has 1054 observations with a median of $15.27 \%$, which is, surprisingly, far above the minimum capital requirement of $4 \%$ proposed by the BCBS. However, non-risk-based measures have more than twice as many observations. For example, tangible common equity to tangible assets has a total of 2515 observations with a median value of $11.33 \%$. The number of missing observations can be explained by the fact that most countries started reporting their capital requirements information in 2006 or that some banks prefer not to provide information about their capital adequacy ratios and would rather provide information about their traditional capital ratios. These countries might still be working under the Basel I accord or prefer not to disclose information about their risk weighting, and thus their assets' risk exposure.

[Insert Table 1 around here]

\subsection{Main results}

We use the following OLS regression model to examine the relationship between capital, risk and bank performance:

$\mathrm{f}(\text { LLRGLP, CIRP, EARTAP })_{\mathrm{ijt}}=\alpha+\varphi \times$ bank_control $_{\mathrm{ijt}}+\beta \times$ Capital_ra $_{\mathrm{ijt}}+\varepsilon_{\mathrm{ijt}}$

The dependent variables are banks' LLRGLP, CIRP and EARTAP in country $\mathrm{j}$ in year t, as defined in the previous section. The main independent variables are the capital ratios, as

\footnotetext{
${ }^{7}$ We thank an anonymous reviewer for comments on the negative minimum value of net interest margin and small values of Tier 2 capital. The negative value of net interest margin indicates that in some cases bank interest expenses exceed interest income, suggesting a bad financial decision where the bank's performance might be at risk. An example of negative values of net interest margin can be found in previous works such as Abedifar et al. (2013). The small-value Tier 2 capital means that the bank is avoiding the usage of hybrid capital and the instruments of subordinated debt. As a complementary element, Basel III requires banks to reduce the value of Tier 2 and improve the value of Tier 1 because Tier 1 represents capital of a good quality. Examples of negative or null values of Tier 2 are reported in papers such as Demirgüç-Kunt et al. (2013) and Anginer and DemirgüçKunt (2014).
} 
expressed in the previous section. ${ }^{8}$ The bank-level control variables incorporate bank size, bank loan engagement, growth of total assets, income diversity ratio and bank cost or risk, depending on the equation. ${ }^{9}$

The results of Eq. (1) are presented in Table 2 and show a positive and significant association between capital and risk in five out of eight definitions of capital ratios (Models 2 to 6). The results clearly show that banks with higher capital ratios have higher loan loss reserves to be commensurate with the amount of risk taken, thereby giving support to the role of the Basel Accords (Altunbas et al., 2007; Iannotta et al., 2007). According to Arnold et al. (2012), three lessons are learned from the establishment of a regulatory capital ratio: (i) more capital is important; (ii) capital ratios should be based on some measures of risk; and (iii) some capital is better than other capital. Our results clearly show that higher levels of capitalization compensate for riskier assets (Iannotta et al., 2007).

\section{[Insert Table 2 around here]}

Table 3 and Table 4 report a negative and significant impact of capital on bank inefficiency (all the models except Models 2 and 5) and a positive and significant effect on bank profitability (all the models except Model 5). Therefore, higher capital ratios ameliorate bank efficiency and profitability. Our results are similar to those obtained in the literature (Iannotta et al., 2007; Pasiouras, 2008; Ben Naceur and Omran, 2011; Chorterareas et al., 2012; Barth et al., 2013; Lee and Hsieh, 2013). These authors explain that higher capital requirements help to discipline banks' activities and increase supervision and monitoring and therefore bank efficiency and profitability. Finally, we find that other forms of capital or capital-like instruments of debt (Tier 2) do not show any significant impact on bank efficiency and profitability; rather, the association becomes negative and significant in Table 4 Model 2. Arnold et al. (2012) explain that the greater creativity in the capital markets gave birth to new

\footnotetext{
${ }^{8}$ Except for the capital ratios, all the correlation coefficients are below 0.4. Therefore, we run each model using only one measure of capital to avoid multicollinearity. The Pearson correlation matrix is available from the authors upon request.

${ }^{9}$ We follow the work of Beck et al. (2013) and Anginer and Demirgüç-Kunt (2014) and cluster on the bank level instead of the country level for two reasons. First, some countries have significant numbers of observations compared with other countries in the sample. Second, we only have 17 countries. Therefore, clustering at the country level might create biased results.
} 
forms of capital (or capital/debt-like) that can be considered in the capital/risk formula. However, the severe impact of the subprime crisis demonstrated that "some capital is better than other capital" (Arnold et al., 2012, p. 3131). Therefore, an emerging literature is showing that imposing complex regulatory requirements that use risk-weighted assets and combine debt instruments with capital of good quality could make banks even riskier than before (Cathcart et al., 2015; Dermine, 2015; Haldane, 2012). Dermine (2015) puts forward five reasons for criticizing Pillar 1 risk-weighted assets and the Basel II/III capital ratio (p. 266): “(i) insufficient capital in a recession, (ii) complexity, (iii) openness to gaming, (iv) lack of robustness, and (v) fear of excessive leverage." One solution is that a complex capital measure should be followed by a non-risk-based leverage ratio (Blum, 2008; Cathcart, 2015; Dermine, 2015), such as Tier 1 to unweighted assets, as required in the Basel III framework. This helps to avoid any inaccurate assessment in quantifying risk.

[Insert Table 3 around here]

With respect to our control variables, we find that larger banks are less risky, more profitable and more efficient because they benefit from economies of scale and a good risk management and monitoring policy. Growth of total assets is positively associated with bank profits and negatively associated with bank risk. Thus, year-to-year growth in total assets helps banks to benefit from their expansion strategies to invest more in risk management and credit monitoring, which could decrease any potential credit default and thus ameliorate bank profits. Higher proportions of net loans in bank total assets reduce bank risk and ameliorate bank efficiency and profits. Accordingly, a higher level of engagement in traditional banking activities, such as loans, requires fewer reserves to protect against credit default than other nontraditional banking activities. It appears that banks in the MENA region rely more on traditional activities ${ }^{10}$ (PWC, 2014), making them more cost-efficient, which can be translated

\footnotetext{
${ }^{10}$ Khasawneh and Hassan (2008) explain that regulatory pressure and constraints, in addition to political, economic and technological deficiencies in MENA countries, prevent the banking system from using financial innovation and other types of nontraditional activities. Another reason that could make MENA banks more vigilant in using financial derivatives is the number of bankrupted banks during the 2007/2008 financial crisis due to the over usage of nontraditional activities such as derivatives and other toxic financial products. Finally, the financial markets in the MENA region are less efficient and immature, which reduces opportunities to invest in new and complex nontraditional financial products.
} 
into higher profitability ratios. The income diversity ratio increases bank risk but reduces bank inefficiency and ameliorates bank profits. Unlike loans to assets, a higher ratio means diversification towards nontraditional activities. This could explain the positive association with bank risk whereby banks in the MENA region anticipate higher default risk as they move towards nontraditional activities. However, as with the loans-to-assets ratio, greater diversification ameliorates bank profits and efficiency. Finally, we find no evidence of a significant association between the loan loss reserves ratio and the bank cost-to-income ratio. We also find that the loan loss reserves and profitability ratios are negatively associated.

[Insert Table 4 around here]

\subsection{Robustness tests: bank size, too-big-to-fail, liquidity, the financial crisis and other tests}

We follow the work of Anginer and Demirgüç-Kunt (2014) to examine any crosssectional heterogeneity in the association between capital, risk and bank performance. ${ }^{11}$ Accordingly, we examine whether our results hold for too-big-to-fail banks (tbtfa), highly liquid banks (h_liquid), banks in GCC countries (GCC_dum) versus banks in non-GCC countries (NGCC_dum), banks during the subprime crisis period (crisis) versus banks during normal times (normal) and finally the impact of the world governance indicator (world_gov) on banks in GCC countries vs. non-GCC countries.

Table 5 reports the results for too-big-to-fail banks using the following OLS regression:

$$
\mathrm{f}(\text { LLRGLP }, \text { CIRP, EARTAP })_{\mathrm{ijt}}=\alpha+\varphi \times \text { bank_control }_{\mathrm{ijt}}+\beta_{1} \times \text { Capital_ra }_{\mathrm{ijt}}
$$$$
+\beta_{2} \times \text { Capital_ra } \mathrm{ijt}_{\mathrm{i}} \times \operatorname{size}(\text { or tbtfa })+\varepsilon_{\mathrm{ijt}}
$$

Here, we can argue from two interconnected perspectives. The first posits that being a too-big-to-fail bank makes the effect of capital requirements on bank risk and performance less important. The second perspective focuses on the fact that larger banks exist in several markets in different countries, engage in nontraditional activities and tend to have higher

\footnotetext{
${ }^{11}$ Our sample is dominated by Lebanese and Egyptian banks. To avoid any biased results, we dropped both countries from the sample to examine the robustness of our results. Our findings, however, are not sensitive to this.
} 
profits and thus higher retained earnings in their capital buffer. Higher capital requirements can also reduce agency cost between bank owners and depositors, resulting in better performance. We interact capital ratios with bank size (size) (Panel A) and the too-big-to-fail dummy $^{12}$ (tbtfa) (Panel B) to examine whether the results persist for large banks. Our findings suggest that a higher level of capital is less effective in requiring bigger banks to adjust their loan loss reserves according to the Basel methodology. However, Table 5 Panel A and Panel B show that larger banks with higher capital ratios are more cost-efficient and more profitable. Our results are consistent with Anginer and Demirgüç-Kunt (2014) for the association between capital and risk. If larger banks benefit from implicit too-big-too-fail guarantees and governmental bailouts, then they will be less interested in holding higher capital ratios. Finally, the positive effect of capital on the performance of large banks suggests that capital ratios are more effective in reducing costs. Capital also plays a key role as a signal of bank asset quality and thus its performance (Demirgüç-Kunt et al., 2013).

\section{[Insert Table 5 around here]}

Besides capital of good quality and additional capital buffers, Basel III introduces a new framework for liquidity risk that "establishes minimum levels of liquidity for internationally active banks" (Arnold et al., 2012). Therefore, we control for liquidity and interact the capital ratios with a dummy variable (h_liquid) to determine whether the results hold for highly liquid banks. ${ }^{13}$ We also use Eq. (2) and replace size with $\mathrm{h}$ _liquid. Table 6 Panel A shows that the effect of capital ratios on risk is more pronounced for highly liquid banks, while the results are not significantly different for the efficiency and profitability models. Therefore, more liquid banks have a more effective policy in protecting against risk and this could be achieved by holding higher loan loss reserve ratios. As for efficiency and profitability, the interaction terms suggest that increased capital ratios for highly liquid banks did not penalize their performance. Perhaps this reflects the fact that banks in the MENA region prefer to hold liquid assets in the form of governmental and Central Banks bonds instead of long term risky investments, as well as liquid assets in the form of mortgage backed securities. This is due to

\footnotetext{
${ }^{12}$ Based on the upper quantile (Q75), banks are classified as too-big-to-fail when LnTA>15.827.

${ }^{13}$ Based on the upper quantile (Q75), banks are classified as highly liquid when liquid assets to assets $>43.922$.
} 
MENA's underdeveloped financial markets and lack of expertise in evaluating complex financial instruments. For instance, the usage of financial derivatives was the main reason behind the deterioration of asset quality that made many western banks illiquid, and negatively affected their performance once the subprime crisis emerged (Demirgüç-Kunt et al., 2013).

[Insert Table 6 around here]

To investigate whether our results are the same for $\mathrm{GCC}^{14}$ and non-GCC countries, we create two separate dummy variables that represent GCC countries and the rest of the MENA countries. Then, we interact both of them with our capital ratios. The results are reported in Table 6 Panel B and suggest no significant difference between the two regions. However, it is interesting to note that the Tier 2 ratios (risk-weighted and non-risk-weighted) show different impacts on the two regions. We find that higher Tier 2 ratios have a positive and marginal impact on loan loss reserves but reduce bank efficiency and profitability in the non-GCC countries. This could be explained by the fact that banks in GCC countries are more experienced with capital-like instruments than banks in the rest of the MENA countries. Benefiting from the oil boom, ${ }^{15}$ banks in the GCC region attract talented managers, along with skilled and competent employees. They also benefit from connections and the expertise of many Western banks operating in the Gulf region. In addition, GCC governments are working on developing their own regulatory framework (Ben Naceur and Omran, 2011). By adhering to the Basel III capital framework, GCC banks are strengthening the capacity of their banking system to absorb financial shocks, enhance risk management and improve transparency. Eventually, this can be reflected in a better understanding of hybrid capital and financial instruments that can be integrated into the capital-like element of the capital measure.

\footnotetext{
${ }^{14}$ The GCC countries include Bahrain, Kuwait, Oman, Saudi Arabia, Qatar and the United Arab Emirates. To separate the GCC countries from the rest of the MENA countries, we implement a GCC dummy (GCC_dum) that takes the value of 1 for GCC countries and 0 otherwise. In addition, we use a non-GCC dummy (NGCC_dum) that takes the value of 1 for non-GCC countries and 0 otherwise.

15 This is relative since GCC economies are more vulnerable to fluctuations in oil prices.
} 
In their study, Anginer and Demirgüç-Kunt (2014) use data from Laeven and Valencia's (2008) work to examine the relationship between bank capital and risk in the crisis period. However, after examining an updated version of Laeven and Valencia's (2012) work on banking crisis periods, we find a small number of countries operating in the MENA region that were affected during the period between 1999 and 2011. Therefore, we follow the work of Abedifar et al. (2013) and Beck et al. (2013) and consider 2008-2009 as the crisis period. Accordingly, we use a crisis time dummy (crisis) that takes the value of 1 in 2008-2009 and 0 otherwise. We also add another dummy (normal) that - in contrast to the crisis dummy represents the normal time period. As with banks in the GCC countries and non-GCC countries dummy variables, we include an interaction term between the capital ratios, the crisis time dummy and the normal time dummy. Table 6 Panel $\mathrm{C}$ shows no significant difference between the normal time and the crisis time. Banks with higher capital ratios have higher loan loss reserves, lower costs and higher profitability during the crisis time as well as the normal time period. Accordingly, capital matters for banks because of its ability to absorb losses as well as its role in reflecting bank asset quality. Our findings are similar to Anginer and Demirgüç-Kunt (2014) who find that capital was successful in reducing bank systemic risk even for the period that followed the subprime crisis.

Finally, to examine whether a country's good governance has an influence on the impact of capital on risk and bank performance, we use the world governance indicator (world_gov) as computed by Kaufmann et al. (2006). This indicator combines six dimensions of governance. These dimensions reflect the capacity of citizens to choose their own government, the country's political stability and the absence of violence, the government's effectiveness, the regulatory quality, the rule of law and the control of corruption. We interact this indicator with capital ratios for banks in the GCC region and the rest of the banks in the MENA region to gauge any differences in the specific institutional variables between the two regions. The results are reported in Table 6 Panel D. We find that good governance has a more pronounced effect on the association between capital and risk in both regions. We even find that ratios such as common equity/ta and tangible equity/ta are now positively associated with the loan loss reserve ratio. In addition, we find that the positive impact of capital ratios 
on bank performance is more important in magnitude in countries and regions with good governance. This suggests that a better institutional environment in terms of law and regulation, a democratic and transparent political system, a higher degree of freedom of expression and free media, and non-corrupt markets allow bank managers and regulators to more effectively monitor and screen risk and control for cost, thereby improving the relationship between capital, risk and bank performance.

\subsection{Robustness tests: controlling for the Arab Spring}

One major event that the MENA region has witnessed is the Arab Spring. In the aftermath of the financial crisis, the MENA countries recovered rapidly compared with Western countries, boosted by oil prices and the weak use of toxic financial instruments. However, by the end of 2010, political revolutions began to emerge. These revolutions overthrew several political regimes, which caused several Arab countries to suffer from instability and economic problems. Ghosh (2015) finds that the Arab revolutions decreased bank profitability and increased bank risk. Therefore, we follow Ghosh's (2015) work ${ }^{16}$ and control for the Arab Spring using two separate equations:

$$
\mathrm{f}(\text { LLRGLP }, \text { CIRP, EARTAP })_{\mathrm{ijt}}=\alpha+\varphi \times \text { bank_control }_{\mathrm{ijt}}+\beta \times \text { PCA_capital_ra }_{\mathrm{ijt}}+
$$

$$
\delta \times \text { GCC_dum } \times \text { AS_1 } 1+\mu \times \text { NGCC_dum } \times \text { AS_1 }+\varepsilon_{i j t}
$$

$$
\begin{aligned}
& \mathrm{f}(\text { LLRGLP }, \text { CIRP, EARTAP })_{\mathrm{ijt}}=\alpha+\varphi \times \text { bank_control }_{\mathrm{ijt}}+\beta \times \text { PCA_capital_ra }_{\mathrm{ijt}} \\
& \times \text { GCC_dum } \times \text { AS_1 }+\delta \times \text { PCA_capital_ra }{ }_{i j t} \times \text { NGCC_dum } \times \text { AS_1 }+\varepsilon_{\text {ijt }}(4)
\end{aligned}
$$

In contrast to Ghosh's (2015) work, we separate GCC countries and the rest of the MENA countries. ${ }^{17}$ We use Eq. (3) to control for the Arab Spring and Eq. (4) to examine the direct impact of the Arab Spring on the association between capital, risk and performance in

\footnotetext{
${ }^{16}$ We use Arab Spring (AS_1), lagged by one year, a dummy variable that equals 1 if a country is severely affected by the Arab Spring and 0 otherwise.

${ }^{17}$ We separate the GCC countries from the rest of the MENA region because political regimes that govern the former are different from the latter. In addition, most of the GCC countries benefit from oil revenues and rapid economic development compared to the rest of the MENA countries. Thus, we expect non-GCC countries to be more vulnerable to political instability, and thus to financial distress.
} 
countries that are more vulnerable to political transition and thus economic instability. PCA_capital_ra ${ }_{i j t}$ is a vector of capital components created using Principal Component Analysis (PCA). ${ }^{18}$ PC1_basel2_rwa represents the overall capital measure. PC2_basel2_tier2 is called the capital-like component. We also exclude Tier 2 capital measures (risk- and nonrisk-based other capital ratios) from PCA and perform another PCA. Accordingly, the PC3_basel2_extier2 component includes all the capital ratios (risk- and non-risk-weighted measures) but excludes the Tier 2 ratios. The last component, PC4_trad_capital, is called the traditional capital measure and excludes risk-based capital ratios and Tier 2 ratios.

The results of Eq. (3) are presented in Table 7 Panel A for the main dependent variables and Panel B for the alternative risk and performance measures. We find that banks with higher capital components have higher reserves for loan loss, lower cost-to-income ratios and higher profitability ratios. As for the impact of the Arab Spring, our results indicate that political instability has a negative impact on bank profitability in the GCC countries (Panels A and B, Models 9, 11 and 12) and on bank efficiency in the rest of the MENA countries (Panel A, Models 5 to 8). The latter are more sensitive to political instability because revolutions are often longer in terms of time intervals and more complex in terms of agreement between political parties. Accordingly, political uncertainty can be rapidly reflected in the development of the economic sector, especially as the rest of the MENA countries do not have natural resources like those of GCC countries. In such circumstances, banks in the rest of MENA are required to spend even more money to provide a better risk management, monitoring and supervision of projects. We also notice that banks in the GCC countries require lower NIMP than banks in the rest of the MENA countries. One possible explanation is that the higher level of cost inefficiency in the non-GCC countries resulted in higher rates on loans. Another explanation is provided by Ghosh (2015): Banks demand higher interest margins in

\footnotetext{
${ }^{18}$ To perform PCA, several steps need to be respected (Canbas et al., 2005; Shih et al., 2007; Klomp and de Haan, 2012). First, the capital ratios need to be highly correlated. Second, we consult the measure of sampling adequacy (MSA). If a variable's MSA is lower than 0.5, this variable is unacceptable and should be removed from the PCA (a higher MSA, e.g. >0.7, means that the variable is important and included in the PCA). Third, all the financial ratios are standardized with a mean of 0 and a standard deviation of 1 . Fourth, the choice of our latent variables depends on the eigenvalues and percentage of total variance. Therefore, we only consider components with eigenvalues greater than 1 and variance greater than 10\%. The tables' details (i.e. the eigenvalues of the components and the component loadings) are not reported to save space but are available from the authors upon request.
} 
anticipation of a higher percentage of nonperforming loans. This is confirmed by our empirical results (Panel B, Models 1 to 3), in which we find a positive impact of the Arab Spring on the nonperforming loans ratio. Therefore, our results are consistent with the previous research in which political changes adversely affect bank risk and performance (Ghosh, 2015).

[Insert Table 7 around here]

Table 8 Panel A and Panel B present the direct impact of the Arab Spring on the association between capital, risk and bank performance. ${ }^{19}$ The results suggest that capital is more effective in requiring banks to hold higher reserves for loan loss in anticipation of more nonperforming loans in the period and countries of the Arab Spring. The results also show that higher capital ratios ameliorate bank efficiency, net interest margin and profits in NGCC countries during the period of Arab revolutions. Banks with higher capital ratios are more prudent and employ a wiser risk management (Anginer and Demirgüç-Kunt et al., 2014), resulting in increased supervision and monitoring (Chortareas et al., 2012; Demirgüç-Kunt et al., 2013), especially in periods of distress such as political instability. Accordingly, capitalized banks that are compliant with regulatory guidelines are likely to perform better than less capitalized banks in periods of political instability, resulting in higher efficiency and profitability. The impact of capital is more pronounced for NGCC countries because they have witnessed severe political perturbation (for example, Tunisia, Libya, Egypt and Syria) compared to GCC countries. Therefore, capital requirements are an important determinant of bank risk and performance in periods of political instability.

[Insert Table 8 around here]

\subsection{Robustness tests: addressing endogeneity}

We complement our analysis by emphasizing the important role of a regulatory environment when examining the association between bank capital, risk, efficiency and

\footnotetext{
${ }^{19}$ We only use the PC1_basel2_rwa and PC3_basel2_extier2 capital components of Basel II. We choose Basel II capital components to investigate whether risk-weighted assets are more effective during stressful situations, such as the Arab Spring.
} 
profitability. These institutional variables may be associated with a possible endogeneity problem. Barth et al. (2013) argue that a potential endogeneity problem may be related to reverse causality. For instance, a risky bank with higher performance may have an important influence on the regulatory policies, for example the Basel Accords' capital guidelines, in the sense of being more indulgent to the development and growth of the bank. Thus, capital requirements may be endogenous to the structure of the banking sector in each country. To address this endogeneity concern, we use: (1) the lagged values of our independent variables, and (2) an Instrumental Variables (IV) approach, which consists of two-stage regressions.

Literature reports mixed views regarding the use of lagged (Demirgüç-Kunt et al., 2013; Anginer and Demirgüç-Kunt, 2014) versus non-lagged (Altunbas et al., 2007; Banker et al., 2010; Hsiao et al., 2010; Chortareasa et al., 2012; Barth et al., 2013) independent variables when examining the impact of banking regulation on bank risk and performance. Thus, in a first step we hypothesize that regulatory ratios might take one year to show its pronounced effect. In addition, a one-year lag of independent variables reduces any concerns about endogeneity. Therefore, we lagged our capital ratios by one year to examine the robustness of our results. Table 9 Panel A and Panel B report similar results for our main variables of interest as well as our alternative risk and performance measures, thereby confirming our earlier findings.

[Insert Table 9 around here]

In a second step, we use an IV approach. First, IV regresses each of our eight proxies of capital requirements on instruments and regressors as reported in baseline models (Table 2 to Table 4). Second, the predicted values of different capital ratios replace these ratios in baseline models. Current literature on capital requirements (Chortareas et al., 2012; Anginer and Demirgüç-Kunt, 2013; Demirgüç-Kunt et al., 2014) is largely silent about endogeneity and the lack of specific instruments that can be used when examining the association between capital and risk and capital and bank performance. In this study, we use the World Governance (world_gov) index as an instrument. Computed by the World Bank, it reports 
aggregate and individual governance indicators for 215 economies worldwide. ${ }^{20}$ The index is basically the result of a survey by Kaufmann et al. (2006) reflecting the responses of a large number of enterprises, citizens and experts in industrial and developing countries. We use this index because it captures the institutional environment that plays a key role in shaping the financial development of economies. Moreover, we argue that it is less likely that the World Governance Index would have a direct effect on banking performance today. Instead, it might affect bank risk and performance through its impact on banking regulation, in particular capital requirements as reported in Table 6 Panel D.

\section{[Insert Table 10 around here]}

We follow Beck et al. (2009) and conduct an F-test of the excluded exogenous variables in the first-stage regressions. The null hypothesis of the test is that our instrument does not explain cross-sectional differences in capital regulatory guidelines and measures. We reject the null hypothesis at the $1 \%$ level in almost all models. The results of the first-stage regressions mainly show that smaller and more efficient banks have higher capital ratios. In addition, the World Governance Index is positively and significantly associated with capital ratios in almost all models. The results of the second-stage regressions are reported in Table $10 .{ }^{21}$ We use different estimation techniques. In Panel A we use Two Least Squares regression (2SLS), in Panel B we use Limited Information Maximum Likelihood (LIML) and in Panel C we use Generalized Method of Moments (GMM). The second stage regression results show a clear evidence of a positive and significant association between capital, risk and bank performance in almost all models and across different estimation techniques. These results provide additional support for our earlier findings and suggest that results are not driven by endogeneity.

\footnotetext{
${ }^{20}$ For more details, see Section 4.3.

${ }^{21}$ We only report Chi2 and capital coefficients from the second-stage regressions and F-tests from the first-stage regressions to save space. Complete results for the first- and second-stage regressions are available from the authors upon request.
} 
In this section, we perform quantile regressions to highlight whether the capital components solution differs across risk and performance quantiles. One important feature of quantile regressions $^{22}$ is that they allow for heterogeneous solutions to PCA capital components by conditioning on bank risk (less risky vs. highly risky), efficiency (less efficient vs. highly efficient) and profitability (less profitable vs. highly profitable). Accordingly, we use the following equation:

$\mathrm{f}(\text { LLRGLP }, \text { CIRP, EARTAP })_{\mathrm{ijt}}=\alpha+\varphi \times$ bank_control $_{\mathrm{ijt}}+\beta \times$ PCA_capital_ra $_{\mathrm{ijt}}+\varepsilon_{\mathrm{ijt}}(5)$

Figures 1, 2 and 3 plot the quantile and the least squares regression estimates for all the components specified in the risk, efficiency and profitability models, respectively. For each covariate, we plot the quantile regression estimates for capital components as a function of quantiles ranging from 0.05 to 0.95 , shown as the point wise solid curve. The shaded gray band illustrates the conventional $90 \%$ confidence interval, estimated using the bootstrapping technique. The long dashed line is the OLS estimate and the two dotted lines characterize a confidential band.

Figure 1 shows the important differences between OLS and quantile regressions. Each of the PCA components shows that the effect of capital ratios is more important in magnitude at the upper tail of the risk component. This is not shown in the OLS graphs. Figure 1 suggests that banks with higher capital ratios are more sensitive to risk - especially riskier banks - and prefer to increase their loan loss reserve ratio as a precautionary policy against risk, which coincides with the Basel recommendation that banks need to increase their capital commensurably with the amount of risk taken.

Figure 2 shows that highly efficient banks are more responsive to capital requirements than less efficient banks. In other words, the negative impact of capital on cost inefficiency is more important in magnitude for highly efficient banks than less efficient ones.

\footnotetext{
${ }^{22}$ The quantile regression results are also robust to outliers and distributions with heavy tails. The quantile regression also avoids the restrictive assumption that the error terms are identically distributed at all points of the conditional distribution.
} 
Figure 3 suggests a positive and significant association between capital and profitability. The results appear to be stronger as the profitability ratio moves up towards the upper quantile.

[Insert Figures 1, 2, 3 around here]

We note that the capital-like (or PC2_basel2_tier2) component does not show the same pattern as the rest of the capital components in any of the three models (risk, efficiency and profitability); rather, it shows a destabilizing effect. Arnold et al. (2012) argue that the use of some capital is better than the use of other capital, while Dermine et al. (2015) explain that the BCBS Basel III Accord directs much more attention to common equity Tier 1 than other capital. Our results are in line with the BCBS and the two authors' recommendations regarding banks in the MENA region.

Finally, we examine the robustness of our results using four alternative estimation methods. First, we use the bootstrapping techniques with a random resample of 100 of the 168 banks employed in our initial sample. We also correct for the heteroscedasticity of the standard errors. The results are presented in Table 11 Panel A and show that our results are more significant than before. Second, we use a fixed-effect model. The results are presented in Table 11 Panel B and show that the results are even stronger than our earlier regressions. Third, we use a random-effect regression model. The results are provided in Table 11 Panel C and show the same outcome. ${ }^{23}$ Finally, we use the Fama and MacBeth (1973) estimation technique to check for cross-sectional dependence. Table 11 Panel D shows that the results are even more robust.

[Insert Table 11 around here]

\footnotetext{
${ }^{23}$ We also performed a Hausman test to determine whether to choose random-effect or fixed-effect models. However, the results altered between the two models depending on capital measures. Therefore, we present the results for both models.
} 


\section{Conclusion}

This paper examines the impact of capital requirements on risk and bank performance for a sample of 168 banks in 17 MENA countries for the 1999-2013 period. We find that banks with higher capital ratios have higher loan loss reserves, are more efficient and are more profitable. The impact of capital requirements on bank efficiency and profitability is more important for too-big-to-fail banks and banks in countries with good governance. Higher capital in countries with an appropriate institutional environment can influence the investment strategies of larger banks towards more careful lending activities, prudent risk management and better supervision. This results in a better alignment of interests between bank owners and depositors, which reduces agency costs and ameliorates bank performance. The results persist only for the risk model when studying highly liquid banks. In addition, we find some differences in the effect of capital ratios when comparing banks in GCC countries with banks in the rest of the MENA region and banks during crisis time with banks during normal times, especially for capital-like ratios. Finally, an instrumental variables approach, alternative risk and performance measures, a principal component analysis, an examination of the Arab Spring period and other estimation techniques show very consistent results.

Our results have important implications for regulators and policymakers in the MENA region. First, both risk-based and non-risk-based capital ratios have a pronounced effect on bank risk and performance. Therefore, the regulatory authorities in the MENA region need to promote the application of Basel III, which ameliorates bank efficiency and profitability, and bank protection against risk, especially in periods of stress, such as the financial crisis and the Arab Spring. Second, banks in the MENA region are less capable of dealing with capital-like ratios than those in GCC countries. We call on these banks to minimize their use of Tier 2 ratios and regulators to be more prudent with banks that implement higher Tier 2 ratios in their capital. Finally, we show that the capital-like (Tier 2) element is more sensitive to loan loss reserves than capital of good quality (Tier 1 or common equity). Thus, banks are encouraged to increase the Tier 1 element in their capital adequacy ratio rather than the Tier 2 element. 
We find a number of limitations in our study. First, the sample is limited because there are many missing observations, especially for the period between 1999 and 2005. In addition, risk-based regulatory capital ratios are less available than the rest of the accounting measures. Accordingly, the additional econometric tests are limited due to the lack of availability of historical financial data. Second, we did not include market-based financial measures because most banks are unlisted. Finally, we find no studies that mainly focus on the impact of capital requirements on the risk and bank performance in the MENA region. Accordingly, our results and analyses are mainly inspired by the regulatory literature of developed countries.

As regards future work, the research must be intensified when it comes to the banking regulation in the MENA region. Studies should be deepened when adapting the Basel III guidelines to banks in this region, especially as banking regulation depends on many internal and external heterogeneous factors. Applying a one-size-fits-all regulatory framework might penalize bank activities in one region compared with another. Therefore, we believe that comparative empirical studies between banks in the MENA region and banks in European countries or the United States are necessary to understand whether banks need to apply the different regulatory guidelines. The same is applicable for capital requirements and thus its impact on bank activities and funding strategies. 


\section{References}

Abedifar, P., P. Molyneux and A. Tarazi, 2013, 'Risk in Islamic banking', Review of Finance, Vol.17, pp. 2035-2096.

Agusman, A., G.S. Monroe, D. Gasbarro, and J.K. Zumwalt, 2008, 'Accounting and capital market measures of risk: evidence from Asian banks during 1998-2003', Journal of Banking \& Finance, Vol. 32, No. 4, pp. 480-488.

Altunbas, Y., S. Carbo, E. Gardner, and P. Molyneux, 2007, 'Examining the relationship between capital, risk and efficiency in European banking', European Financial Management, Vol.13, No.1, pp. 49-70.

Anginer, D. and A. Demirgüç-Kunt, 2014, 'Bank capital and systemic stability', Policy Research Working Paper No. 6948, The World Bank, Washington, DC.

Arnold, B., C. Borio, L. Ellis, and F. Moshirian, 2012, 'Systemic risk, macroprudential policy framework, monitoring financial systems and the evolution of capital adequacy', Journal of Banking \& Finance, Vol.6, No.12, pp. 3125-3132.

Baele, L., O. De Jonghe, and R. Vander Vennet, 2007, 'Does the stock market value bank diversification?’ Journal of Banking \& Finance, Vol.31, No.7, pp. 1999-2023.

Banker, R.D., H. Chang, and S. Lee, 2010, 'Differential impact of Korean banking system reforms on bank productivity', Journal of Banking \& Finance, Vol.34, No.7, 1450 1460.

Barrios, V.E. and J.M. Blanco, 2003, 'The effectiveness of bank capital adequacy regulation: a theoretical and empirical approach', Journal of Banking \& Finance, Vol.27, No.10, pp. 1935-1958.

Barth, J., C. Lin, Y. Ma, J. Seade, and F. Song, 2013, 'Do bank regulation, supervision and monitoring enhance or impede bank efficiency?' Journal of Banking \& Finance, Vol.37, No.8, pp. 2879-2892.

Barth, J., C. Lin, P. Lin, and F. Song, F. 2009, 'Corruption in bank lending to firms: Cross country micro evidence on the beneficial role of competition and information sharing, Journal of Financial Economics, Vol.91, 361-388.

Basel Committee on Banking Supervision, (2014). 'Basel III Leverage Ratio Framework and Disclosure Requirements', Bank for International Settlements, Basel, pp. 1-19.

Beck, T., A. Demirgüç-Kunt, and O. Merrouche, 2013, 'Islamic vs. conventional banking: business model, efficiency and stability', Journal of Banking \& Finance, Vol.37, No.2, pp. 433-447.

Ben Naceur, S. and K. Magda, 2009, 'The Impact of Capital Requirements on Banks' Cost of Intermediation and Performance: The Case of Egypt', Journal of Economics and Business, Vol. 61, No.1, pp. 70-89.

Ben Naceur, S. and M. Omran, 2011, 'The effects of bank regulations, competition, and financial reforms on banks' performance', Emerging markets review, Vol.12, No.1, pp. $1-20$.

Ben Naceur, S. and M. Goaeid, 2008, 'The determinants of commercial bank interest margin and profitability: Evidence from Tunisia', Frontier in Finance and Economics, Vol.5, No.1, pp. 106-130. 
Berger, A.N., 1995, 'The relationship between capital and earnings in banking', Journal of Money, Credit and Banking, Vol.2, No.27, pp. 432-456.

Berger, A.N., 2007, 'International comparisons of banking efficiency', Financial Markets, Institutions \& Instruments, Vol.16, No. 3, pp. 119-165.

Berger, A.N. and D.B. Humphrey, 1997, 'Efficiency of financial institutions: International survey and directions for future research', European Journal of Operational Research, Vol.98, No. 2, pp. 175-212.

Berger, A.N. and C.H.S. Bouwman, 2013, 'How does capital affect bank performance during financial crises?', Journal of Financial Economics, Vol.109, No.1, pp. 146-176.

Blum, J.M., 2008, 'Why Basel II may need a leverage ratio restriction', Journal of Banking \& Finance, Vol.32, No.8, pp. 1699-1707.

Brewer, E. and C.F. Lee, 1986, 'How the market judges bank risk', Economic Perspectives, Vol.10, No.6, pp. 25-31.

Bryant, J., 1980, 'A model of reserves, bank runs, and deposit insurance', Journal of Banking \& Finance, Vol. 4, No.4, pp. 335-344.

Canbas, S., A. Cabuk, and Kilic, S.B. 2005, 'Prediction of commercial bank failure via multivariate statistical analysis of financial structures: the Turkish case', European Journal of Operational Research, Vol.166, No.2, pp. 528-546.

Cathcart, L., L. El-Jahel, and R. Jabbour, 2015, 'Can regulators allow banks to set their own capital ratios?', Journal of Banking \& Finance, Vol.53, No.1, pp. 112-123.

Chortareasa, G.E., C. Girardoneb, and A. Ventouric, 2012, 'Bank supervision, regulation, and efficiency: evidence from the European Union', Journal of Financial Stability, Vol.8, No.4, pp. 292-302.

Creane, S., R. Goyal, A.M. Mobarak, and R. Sab, 2004, 'Financial sector development in the Middle East and North Africa', Working Paper No. WP/04/201, International Monetary Fund, Washington.

Crowley, J., 2008, 'Credit growth in the Middle East, North Africa, and Central Asia region', Working Paper No. WP/08/184, International Monetary Fund, Washington.

Demirgüç-Kunt, A. and E. Detragiache, 2011, 'Basel core principles and bank soundness: does compliance matter?', Journal of Financial Stability, Vol.7,No.4, pp. 179-190.

Demirgüç-Kunt, A., E. Detragiache, and O. Merrouche, 2013, 'Bank capital: lessons from the financial crisis', Journal of Money, Credit and Banking, Vol.45, No.6, pp. 1147-1164.

Demirgüç-Kunt, A. and H. Huizinga, 2000, 'Financial structure and bank profitability', Policy Research Working Paper No. 2430, The World Bank, Washington.

Demirgüç-Kunt, A. and H. Huizinga, 2010, 'Bank activity and funding strategies: the impact on risk and returns', Journal of Financial Economics, Vol.98, No.3, pp. 626-650.

Demirgüç-Kunt, A. and E.J. Kane, 2001, 'Deposit insurance around the globe: where does it work?', Working Paper No. 8493, National Bureau of Economic Research.

Dermine, J., 2015, 'Basel III leverage ratio requirement and the probability of bank runs', Journal of Banking \& Finance, Vol.5, No.1, pp. 266-277.

Diamond, D.W. and P.H. Dybvig, 1983, 'Bank runs, deposit insurance, and liquidity', Journal of Political Economy, Vol.91, No.3, pp. 401-419.

Fama, E. and J. MacBeth, 1973, 'Risk, return, and equilibrium: empirical tests', Journal of Political Economy, Vol.81, pp. 607-636. 
Flamini, V., C. McDonald, and L. Schumacher, 2009, 'The determinants of commercial bank profitability in Sub-Saharan Africa', Working Paper No. WP/09/15. International Monetary Fund, Washington.

Fiordelisi, F., D. Marques-Ibanez, and P. Molyneux, 2011, 'Efficiency and risk in European banking', Journal of Banking \& Finance, Vol.35, No.5, pp. 1315-1326.

Furlong, F. and M.C. Keeley, 1989, 'Capital regulation and bank risk taking: a note', Journal of Banking \& Finance, Vol.13, No.6, pp. 883-891.

Ghosh, S. 2015, 'Political transition and bank performance: how important was the Arab Spring?', Journal of Comparative Economics, forthcoming.

Haldane, A.G. 2012, 'The Dog and the Frisbee', Bank of England, United Kingdom.

Hsiao, H., H. Chang, A.M. Cianci, and L. Huang, 2010, 'First financial restructuring and operating efficiency: Evidence from Taiwanese commercial banks', Journal of Banking \& Finance, Vol.34, No.7, 1461-1471.

Iannotta, G. 2006, 'Testing for opaqueness in the European banking industry: evidence from bond credit ratings', Journal of Services Research, Vol.31, No.3, pp. 2127-2149.

Iannotta, G., G. Nocera, and A. Sironi, 2007, 'Ownership structure, risk and performance in the European banking industry', Journal of Banking \& Finance, Vol.31, No.7, pp. 2127-2149.

Jacques, K. and P. Nigro, 1997, 'Risk-based capital, portfolio risk and bank capital: a simultaneous equations approach', Journal of Economics and Business, Vol.49, No.6, pp. 533-547.

Jahankhani, A. and M.J. Lynge, 1980, 'Commercial bank financial policies and their impact on market-determined measures of risk', Journal of Bank Research, Vol.11, pp. 169178.

Kaufmann, D., A. Kraay, and M. Mastruzzi, 2006, 'Governance Matter V: Worldwide Governance Indicators, 1996-2013', The World Bank, Washington D.C.

Keeley, M.C. and F.T. Furlong, 1991, 'A re-examination of mean-variance analysis of bank capital regulation', Journal of Banking \& Finance, Vol.14, No.1, 69-84.

Kim, D. and A.M. Santomero, 1988, 'Risk in banking and capital regulation', Journal of Finance, Vol.43, No.5, pp. 1219-1233.

Klomp, J. and J. de Haan, 2012, 'Banking risk and regulation: does one solution fit all?', Journal of Banking \& Finance, Vol.36, No.12, pp. 3197-3212.

Klomp, J. and J. de Haan, 2014, 'Bank regulation, the quality of institutions, and banking risk in emerging and developing countries: an empirical analysis', Emerging Market Finance \& Trade, Vol.50, No.6, pp.19-40.

Laeven, L. and R. Levine, 2007, 'Is there a diversification discount in financial conglomerates?', Journal of Financial Economics, Vol.85, No.2, pp. 331-367.

Laeven, L. and F. Valencia, 2008, 'Systemic banking crises: a new database', Working Paper No. WP/08/224, International Monetary Fund, Washington.

Laeven, L. and F. Valencia, 2012, 'Systemic banking crisis database: an update', Working Paper No. WP/12/163, International Monetary Fund, Washington.

Lee, C. and M. Hsieh, 2013, 'The impact of capital on profitability and risk in Asian banking', Journal of International Money and Finance, Vol.32, No.2, pp. 251-281. 
Neyapti, B. and N. Nergiz Dincer, 2014, 'Macroeconomic impact of bank regulation and supervision: A cross-country investigation, Emerging Market Finance \& Trade, Vol.50, No.1, pp.52-70.

Pasiouras, F. 2008, 'International evidence on the impact of regulations and supervision on banks' technical efficiency: an application of two-stage data envelopment analysis', Review of Quantitative Finance and Accounting, Vol.30, No.2, pp. 187-223.

PricewaterhouseCoopers (2014). 'Basel III: A silver lining for Middle East banks'.

Rime, B. 2001, 'Capital requirements and bank behavior: empirical evidence for Switzerland', Journal of Banking \& Finance, Vol.25, No.4, pp. 789-805.

Shih, V., Q. Zhang, and M. Liu, 2007, 'Comparing the performance of Chinese banks: a principal component analysis', China Economic Review, Vol.18, No.1, pp. 15-34.

Staub, R.B., G. Da Silva e Souza, and B.M. Tabak, 2010, 'Evolution of bank efficiency in Brazil: a DEA approach', European Journal of Operational Research, Vol.202, No.1, pp. 204-213.

Stiroh, K. 2004, 'Diversification in banking: Is non-interest income the answer?' Journal of Money, Credit and Banking, Vol.36, No.5, 853-882.

Sufian, F. 2010, 'The impact of risk on technical and scale efficiency: empirical evidence from the China banking sector', International Journal Business Performance Management, Vol.12, No.1, pp. 37-71.

VanHoose, D. 2007, 'Theories of bank behavior under capital regulation', Journal of Banking \& Finance, Vol.31, No.12, pp. 3680-3697.

Vazquez, F. and P. Federico, 2015, 'Bank funding structures and risk: evidence from the global financial crisis', Journal of Banking \& Finance, Vol.61, No.12, pp. 1-14. 
Table 1

Summary of the descriptive statistics

\begin{tabular}{|c|c|c|c|c|c|c|c|c|}
\hline Label & $\mathrm{N}$ & Mean & Median & Std Dev. & Min. & Max. & $\mathrm{P} 25$ & P75 \\
\hline \multicolumn{9}{|l|}{ Risk and performance models } \\
\hline Loan loss reserves/gross loans & 2132 & 9.26 & 5.54 & 10.33 & 0.44 & 62.78 & 3.04 & 11.58 \\
\hline Non-performing loans/gross loans & 1663 & 11.11 & 5.58 & 14.80 & 0.31 & 92.19 & 2.70 & 13.63 \\
\hline Cost to income & 2445 & 51.90 & 47.72 & 23.62 & 14.58 & 155.56 & 35.72 & 62.31 \\
\hline Net interest margin & 2501 & 1.45 & 1.36 & 1.71 & -5.42 & 8.29 & 0.58 & 2.21 \\
\hline Earnings/ta & 2492 & 3.80 & 3.18 & 2.76 & -0.39 & 18.96 & 2.42 & 4.27 \\
\hline Earnings/gross loans & 2482 & 4.51 & 2.80 & 11.02 & -12.98 & 88 & 1.23 & 4.4 \\
\hline \multicolumn{9}{|l|}{ Main variables and control variables } \\
\hline Tier $1 /$ rwa & 1054 & 17.07 & 15.27 & 7.16 & 7.20 & 49.26 & 12.67 & 19.09 \\
\hline Tier 2/rwa & 1049 & 1.858 & 1.27 & 1.83 & 0.1 & 8.2 & 0.52 & 2.7 \\
\hline Total capital/rwa & 1579 & 20.26 & 17.42 & 9.74 & 8.31 & 67 & 14.39 & 22.51 \\
\hline Tier $1 /$ ta & 1064 & 12.24 & 10.61 & 9.11 & 1.1 & 74.97 & 8.20 & 13.34 \\
\hline Tier $2 /$ ta & 1047 & 1.30 & 0.80 & 1.41 & 0.08 & 6.49 & 0.31 & 1.83 \\
\hline Total capital/ta & 1237 & 13.22 & 11.73 & 9.06 & 0.01 & 73.63 & 8.91 & 14.82 \\
\hline Tangible equity/ta & 2515 & 13.57 & 11.33 & 9.79 & 0.75 & 63.06 & 7.92 & 15.59 \\
\hline Common equity/ta & 2515 & 13.07 & 10.65 & 9.78 & 0.97 & 63.06 & 7.58 & 14.85 \\
\hline Size & 2520 & 14.49 & 14.53 & 1.82 & 10.32 & 18.20 & 13.15 & 15.83 \\
\hline Growth assets & 2336 & 16.19 & 11.73 & 23.53 & -30.66 & 140.11 & 3.82 & 21.99 \\
\hline Net loans/ta & 2496 & 45.89 & 46.24 & 20.28 & 1.67 & 99.11 & 30.55 & 60.94 \\
\hline Income diversity & 2296 & 0.43 & 0.39 & 0.35 & 0 & 1.75 & 0.29 & 0.53 \\
\hline
\end{tabular}

Note: The sample covers 168 banks from 17 MENA countries. 
Table 2

Capital and risk model

\begin{tabular}{|c|c|c|c|c|c|c|c|c|}
\hline Variables & $\begin{array}{l}{[1]} \\
\text { LLRGLP }\end{array}$ & $\begin{array}{l}{[2]} \\
\text { LLRGLP }\end{array}$ & $\begin{array}{l}{[3]} \\
\text { LLRGLP }\end{array}$ & $\begin{array}{l}{[4]} \\
\text { LLRGLP }\end{array}$ & $\begin{array}{l}{[5]} \\
\text { LLRGLP }\end{array}$ & $\begin{array}{l}{[6]} \\
\text { LLRGLP }\end{array}$ & $\begin{array}{l}{[7]} \\
\text { LLRGLP }\end{array}$ & $\begin{array}{l}{[8]} \\
\text { LLRGLP }\end{array}$ \\
\hline Size & $\begin{array}{l}-0.668^{* * * *} \\
(0.25)\end{array}$ & $\begin{array}{l}-0.992 * * * \\
(0.29)\end{array}$ & $\begin{array}{l}-1.049 * * * \\
(0.30)\end{array}$ & $\begin{array}{l}-0.76^{* * *} \\
(0.32)\end{array}$ & $\begin{array}{l}-1.8^{* * * *} \\
(0.5)\end{array}$ & $\begin{array}{l}-0.78^{* * * *} \\
(0.1)\end{array}$ & $\begin{array}{l}-1.349 \text { *** } \\
(0.30)\end{array}$ & $\begin{array}{l}-1.314 \text { *** } \\
(0.31)\end{array}$ \\
\hline $\begin{array}{l}\text { Growth } \\
\text { assets }\end{array}$ & $\begin{array}{l}-0.072 \text { **** } \\
(0.01)\end{array}$ & $\begin{array}{l}-0.066^{* * * *} \\
(0.01)\end{array}$ & $\begin{array}{l}-0.079^{* * * *} \\
(0.01)\end{array}$ & $\begin{array}{l}-0.073^{* * * *} \\
(0.01)\end{array}$ & $\begin{array}{l}-0.084 * * * \\
(0.02)\end{array}$ & $\begin{array}{l}-0.069 * * * \\
(0.01)\end{array}$ & $\begin{array}{l}-0.078 * * * \\
(0.01)\end{array}$ & $\begin{array}{l}-0.076 \text { *** } \\
(0.01)\end{array}$ \\
\hline Net loans/ta & $\begin{array}{l}-0.108 * * * * \\
(0.02)\end{array}$ & $\begin{array}{l}-0.121 * * * \\
(0.02)\end{array}$ & $\begin{array}{l}-0.176^{* * * *} \\
(0.03)\end{array}$ & $\begin{array}{l}-0.187 \text { *** } \\
(0.03)\end{array}$ & $\begin{array}{l}-0.217 * * * \\
(0.06)\end{array}$ & $\begin{array}{l}-0.206 * * * \\
(0.03)\end{array}$ & $\begin{array}{l}-0.18^{* * * *} \\
(0.04)\end{array}$ & $\begin{array}{l}-0.18^{* * * *} \\
(0.04)\end{array}$ \\
\hline $\begin{array}{l}\text { Income } \\
\text { diversity }\end{array}$ & $\begin{array}{l}6.148 * * * \\
(1.45)\end{array}$ & $\begin{array}{l}5.846^{* * * *} \\
(0.01)\end{array}$ & $\begin{array}{l}6.272 * * * \\
(1.81)\end{array}$ & $\begin{array}{l}5.067 * * * \\
(1.72)\end{array}$ & $\begin{array}{l}7.917 * * * \\
(2.79)\end{array}$ & $\begin{array}{l}3.28 * * \\
(1.59)\end{array}$ & $\begin{array}{l}6.004 * * * \\
(1.25)\end{array}$ & $\begin{array}{l}6.1 * * * \\
(1.27)\end{array}$ \\
\hline $\begin{array}{l}\text { Cost to } \\
\text { income }\end{array}$ & $\begin{array}{l}0.04 \\
(0.03)\end{array}$ & 0.0312 & $\begin{array}{l}0.013 \\
(0.03)\end{array}$ & 0.05 & $\begin{array}{l}-0.001 \\
(0.05)\end{array}$ & $\begin{array}{l}0.021 \\
(0.03)\end{array}$ & $\begin{array}{l}0.014 \\
(0.03)\end{array}$ & $\begin{array}{l}0.017 \\
(0.03)\end{array}$ \\
\hline Tier 1/rwa & $\begin{array}{l}0.118 \\
(0.09)\end{array}$ & & & & & & & \\
\hline Tier 2/rwa & & $\begin{array}{l}0.399 * * * \\
(0.15)\end{array}$ & & & & & & \\
\hline $\begin{array}{l}\text { Total } \\
\text { capital/rwa }\end{array}$ & & & $\begin{array}{l}0.208 * * * \\
(0.08)\end{array}$ & & & & & \\
\hline Tier $1 /$ ta & & & & $\begin{array}{l}0.504 * * * \\
(0.09)\end{array}$ & & & & \\
\hline Tier $2 /$ ta & & & & & $\begin{array}{l}0.824 * * * \\
(0.28)\end{array}$ & & & \\
\hline $\begin{array}{l}\text { Total } \\
\text { capital/ta }\end{array}$ & & & & & & $\begin{array}{l}0.487 * * * \\
(0.1)\end{array}$ & & \\
\hline $\begin{array}{l}\text { Common } \\
\text { equity/ta }\end{array}$ & & & & & & & $\begin{array}{l}0.2258 \\
(0.14)\end{array}$ & \\
\hline $\begin{array}{l}\text { Tangible } \\
\text { equity/ta }\end{array}$ & & & & & & & & $\begin{array}{l}0.232 \\
(0.14)\end{array}$ \\
\hline Constant & $\begin{array}{l}16.926 * * * \\
(5.57)\end{array}$ & $\begin{array}{l}24.336 \text { *** } \\
(5.21)\end{array}$ & $\begin{array}{l}26.104 * * * \\
(6.26)\end{array}$ & $\begin{array}{l}18.928 * * * \\
(6.02)\end{array}$ & $\begin{array}{l}43.036 \text { *** } \\
(10.89)\end{array}$ & $\begin{array}{l}21.588^{* * *} \\
(5.92)\end{array}$ & $\begin{array}{l}32.654 * * * \\
(6.06)\end{array}$ & $\begin{array}{l}31.737 * * * \\
(6.33)\end{array}$ \\
\hline Observations & 970 & 965 & 1416 & 958 & 946 & 1120 & 1877 & 1877 \\
\hline $\mathrm{R} 2$ & 0.28 & 0.28 & 0.37 & 0.56 & 0.39 & 0.52 & 0.33 & 0.33 \\
\hline
\end{tabular}

Notes: See Appendix A.1 for the variables' definitions. The dependent variable is the bank loan loss reserves to gross loans (LLRGLP). The estimation is based on OLS regressions. Standard errors are clustered at the bank level and reported in parentheses below their coefficient estimates.

* Statistical significance at the $10 \%$ level.

** Statistical significance at the 5\% level.

*** Statistical significance at the $1 \%$ level. 
Table 3

Capital and efficiency model

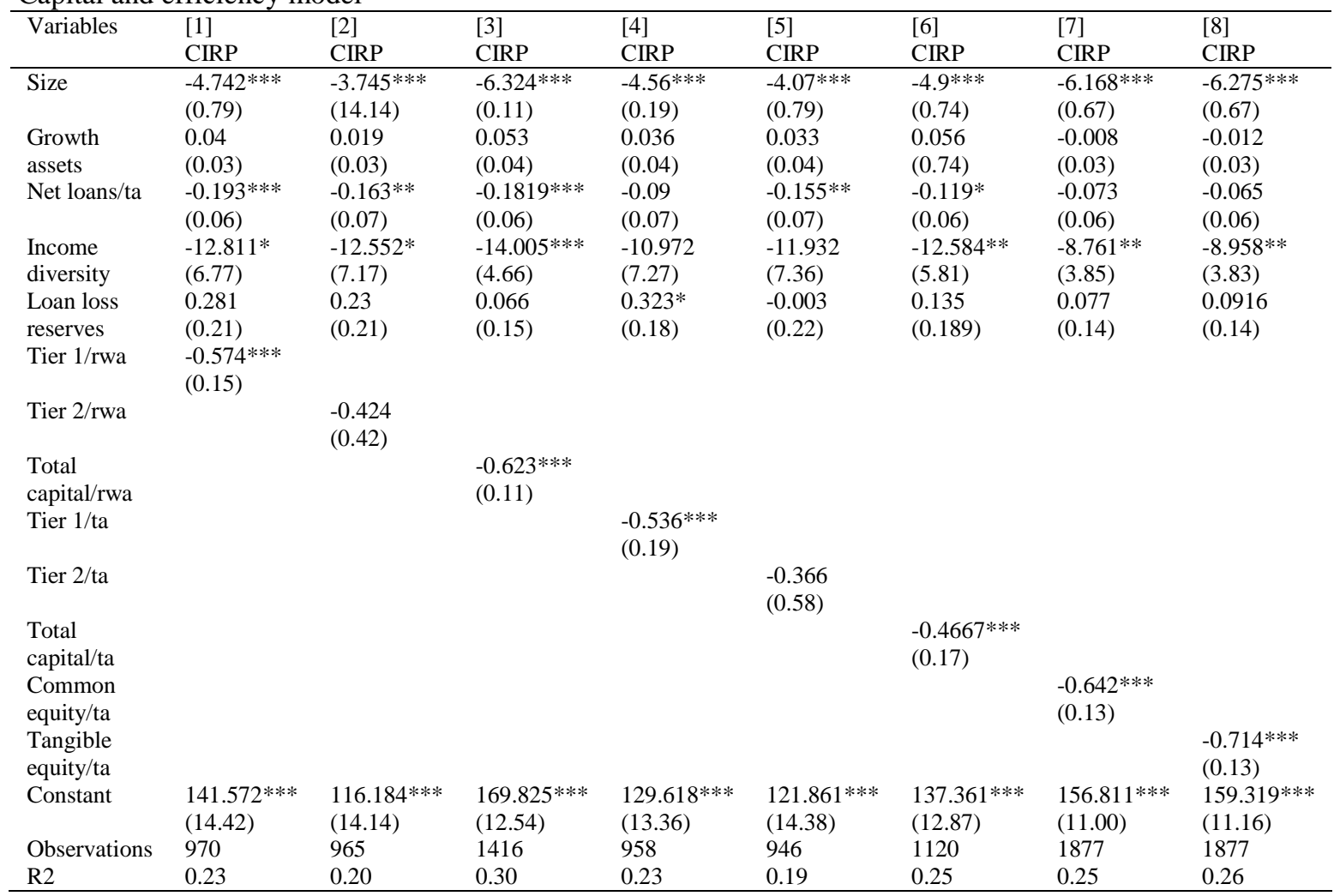

Notes: See Appendix A.1 for the variables' definitions. The dependent variable is the bank cost to income ratio (CIRP). The estimation is based on OLS regressions. Standard errors are clustered at the bank level and reported in parentheses below their coefficient estimates.

* Statistical significance at the $10 \%$ level.

** Statistical significance at the $5 \%$ level.

*** Statistical significance at the $1 \%$ level. 
Table 4

Capital and profitability

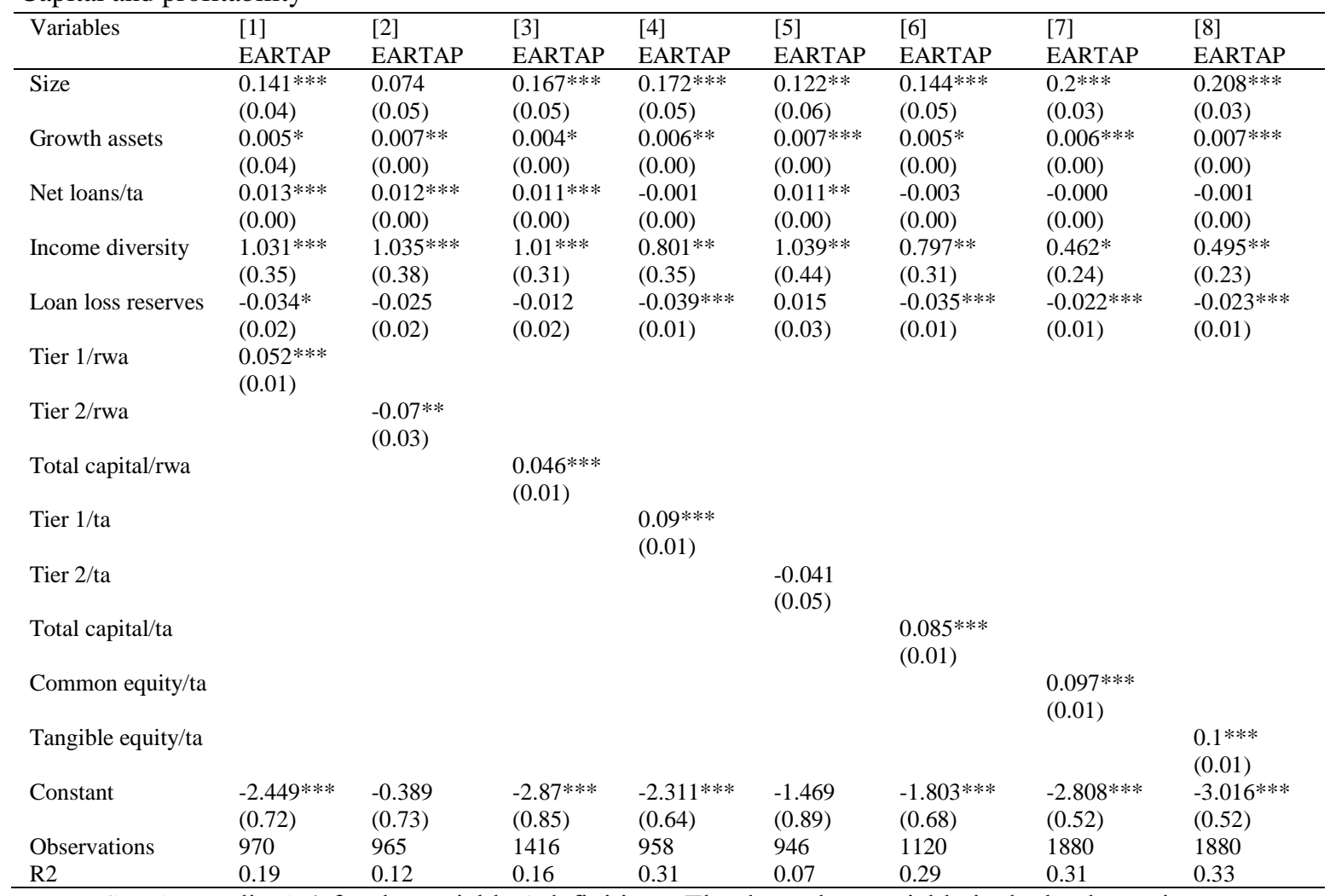

Notes: See Appendix A.1 for the variables' definitions. The dependent variable is the bank earnings to assets (EARTAP). The estimation is based on OLS regressions. Standard errors are clustered at the bank level and reported in parentheses below their coefficient estimates.

* Statistical significance at the $10 \%$ level.

** Statistical significance at the 5\% level.

*** Statistical significance at the $1 \%$ level. 
Table 5

Capital, bank size and too big to fail

\begin{tabular}{|c|c|c|c|c|c|c|c|c|c|}
\hline \multirow[t]{2}{*}{ Variables } & \multicolumn{3}{|c|}{ LLRGLP } & \multicolumn{3}{|c|}{ CIRP } & \multicolumn{3}{|c|}{ EARTAP } \\
\hline & Coef. & $\mathrm{N}$ & $\mathrm{R} 2$ & Coef. & $\mathrm{N}$ & R2 & Coef. & $\mathrm{N}$ & R2 \\
\hline Tier $1 /$ rwa×size & $\begin{array}{l}-0.098 * * \\
(0.04)\end{array}$ & 970 & 0.31 & $\begin{array}{l}-0.214 * * * \\
(0.07)\end{array}$ & 970 & 0.25 & $\begin{array}{l}0.013 * * \\
(0.01)\end{array}$ & 970 & 0.20 \\
\hline Tier 2/rwaxsize & $\begin{array}{l}0.013 \\
(0.12)\end{array}$ & 965 & 0.28 & $\begin{array}{l}0.627 * * \\
(0.3)\end{array}$ & 965 & 0.20 & $\begin{array}{l}-0.012 \\
(0.03)\end{array}$ & 965 & 0.12 \\
\hline Total capital/rwa×size & $\begin{array}{l}-0.063^{*} \\
(0.03)\end{array}$ & 1416 & 0.37 & $\begin{array}{l}-0.162 * * \\
(0.07)\end{array}$ & 1416 & 0.31 & $\begin{array}{l}0.007 \\
(0.00)\end{array}$ & 1416 & 0.16 \\
\hline Tier $1 /$ ta $\times$ size & $\begin{array}{l}-0.085^{* * *} \\
(0.03)\end{array}$ & 958 & 0.58 & $\begin{array}{l}-0.213 * * * \\
(0.05)\end{array}$ & 958 & 0.26 & $\begin{array}{l}0.005 \\
(0.00)\end{array}$ & 958 & 0.31 \\
\hline Tier $2 /$ ta $\times$ size & $\begin{array}{l}-0.111 \\
(0.24)\end{array}$ & 946 & 0.39 & $\begin{array}{l}0.704^{*} \\
(0.42)\end{array}$ & 946 & 0.19 & $\begin{array}{l}-0.058 \\
(0.04)\end{array}$ & 946 & 0.08 \\
\hline Total capital/ta $\times$ size & $\begin{array}{l}-0.084 * * * \\
(0.02)\end{array}$ & 1120 & 0.53 & $\begin{array}{l}-0.28 * * * \\
(0.05)\end{array}$ & 1120 & 0.28 & $\begin{array}{l}0.001 \\
(0.00)\end{array}$ & 1120 & 0.29 \\
\hline Common equity/ta $\times$ size & $\begin{array}{l}-0.088^{* *} \\
(0.04)\end{array}$ & 1877 & 0.35 & $\begin{array}{l}-0.231 \text { *** } \\
(0.07)\end{array}$ & 1877 & 0.27 & $\begin{array}{l}0.01 * * \\
(0.00)\end{array}$ & 1880 & 0.32 \\
\hline Tangible equity/ta $\times$ size & $\begin{array}{l}-0.079 * \\
(0.04)\end{array}$ & 1877 & 0.35 & $\begin{array}{l}-0.259 * * * \\
(0.06)\end{array}$ & 1877 & 0.29 & $\begin{array}{l}0.012 * * \\
(0.00)\end{array}$ & 1880 & 0.34 \\
\hline
\end{tabular}

Panel B: too big to fail

\begin{tabular}{|c|c|c|c|c|c|c|c|c|c|}
\hline \multirow[t]{2}{*}{ Variables } & \multicolumn{3}{|c|}{ LLRGLP } & \multicolumn{3}{|c|}{ CIRP } & \multicolumn{3}{|c|}{ EARTAP } \\
\hline & Coef. & $\mathrm{N}$ & $\mathrm{R} 2$ & Coef. & $\mathrm{N}$ & $\mathrm{R} 2$ & Coef. & $\mathrm{N}$ & $\mathrm{R} 2$ \\
\hline Tier 1/rwaxtbtfa & $\begin{array}{l}-0.326 * * \\
(0.13)\end{array}$ & 970 & 0.29 & $\begin{array}{l}-0.549 * * \\
(0.27)\end{array}$ & 970 & 0.178 & $\begin{array}{l}0.056 \text { *** } \\
(0.02)\end{array}$ & 970 & 0.185 \\
\hline Tier 2/rwaxtbtfa & $\begin{array}{l}0.11 \\
(0.28)\end{array}$ & 965 & 0.26 & $\begin{array}{l}1.755^{* * *} \\
(0.05)\end{array}$ & 965 & 0.169 & $\begin{array}{l}-0.109 * * \\
(0.05)\end{array}$ & 965 & 0.127 \\
\hline Total capital/rwaxtbtfa & $\begin{array}{l}-0.327 * * * \\
(0.12)\end{array}$ & 1416 & 0.36 & $\begin{array}{l}-0.237 \\
(0.21)\end{array}$ & 1416 & 0.179 & $\begin{array}{l}0.012 \\
(0.02)\end{array}$ & 1416 & 0.139 \\
\hline Tier $1 /$ taxtbtfa & $\begin{array}{l}-0.39^{* *} \\
(0.17)\end{array}$ & 958 & 0.56 & $\begin{array}{l}-0.227 \\
(0.39)\end{array}$ & 958 & 0.177 & $\begin{array}{l}0.036 \\
(0.03)\end{array}$ & 958 & 0.291 \\
\hline Tier $2 /$ ta $\times$ tbtfa & $\begin{array}{l}-0.022 \\
(0.51)\end{array}$ & 946 & 0.35 & $\begin{array}{l}2.469 * * \\
(1.00)\end{array}$ & 946 & 0.157 & $\begin{array}{l}-0.161 * * \\
(0.07)\end{array}$ & 946 & 0.076 \\
\hline Total capital/taxtbtfa & $\begin{array}{l}-0.262 \\
(0.15)\end{array}$ & 1120 & 0.52 & $\begin{array}{l}-0.068 \\
(0.34)\end{array}$ & 1120 & 0.181 & $\begin{array}{l}0.000 \\
(0.02)\end{array}$ & 1120 & 0.276 \\
\hline Common equity/ta $\times$ tbtfa & $\begin{array}{l}-0.353 * * \\
(0.16)\end{array}$ & 1877 & 0.32 & $\begin{array}{l}-0.778 * * \\
(0.36)\end{array}$ & 1877 & 0.136 & $\begin{array}{l}0.043 * \\
(0.02)\end{array}$ & 1880 & 0.28 \\
\hline Tangible equity/taxtbtfa & $\begin{array}{l}-0.382 * * \\
(0.16)\end{array}$ & 1877 & 0.32 & $\begin{array}{l}-0.856^{* *} \\
(0.35)\end{array}$ & 1877 & 0.144 & $\begin{array}{l}0.051 \text { ** } \\
(0.02)\end{array}$ & 1880 & 0.298 \\
\hline
\end{tabular}

Notes: See Appendix A.1 for the variables' definitions. The dependent variables are the bank loan loss reserves to gross loans (LLRGLP), the bank cost to income ratio (CIRP) and the bank earnings to assets (EARTAP). In the three models, we only show the variables of interest and the coefficients of the interaction between capital, bank size (size) and the too-big-to-fail dummy (tbtfa) to save space. The estimation is based on OLS regressions. Standard errors are clustered at the bank level and reported in parentheses below their coefficient estimates.

* Statistical significance at the $10 \%$ level.

$* *$ Statistical significance at the $5 \%$ level.

$* * *$ Statistical significance at the $1 \%$ level. 
Table 6

Sub-samples: highly liquid banks, GCC countries, the subprime crisis and governance

\begin{tabular}{|c|c|c|c|c|c|c|c|c|c|}
\hline \multirow[t]{2}{*}{ Variables } & \multicolumn{3}{|c|}{ LLRGLP } & \multicolumn{3}{|c|}{ CIRP } & \multicolumn{3}{|c|}{ EARTAP } \\
\hline & Coef. & $\mathrm{N}$ & $\mathrm{R} 2$ & Coef. & $\mathrm{N}$ & R2 & Coef. & $\mathrm{N}$ & $\mathrm{R} 2$ \\
\hline Tier 1/rwaxh_liquid & $\begin{array}{l}0.075 \\
(0.13)\end{array}$ & 970 & 0.28 & $\begin{array}{l}-0.332 \\
(0.31)\end{array}$ & 970 & 0.24 & $\begin{array}{l}-0.015 \\
(0.02)\end{array}$ & 970 & 0.19 \\
\hline Tier 2/rwaxh_liquid & $\begin{array}{l}1.486^{*} \\
(0.84)\end{array}$ & 965 & 0.29 & $\begin{array}{l}1.636 \\
(1.90)\end{array}$ & 965 & 0.20 & $\begin{array}{l}-0.066 \\
(0.11)\end{array}$ & 965 & 0.13 \\
\hline Total capital/rwaxh_liquid & $\begin{array}{l}0.2 \\
(0.1656)\end{array}$ & 1416 & 0.38 & $\begin{array}{l}-0.128 \\
(0.19)\end{array}$ & 1416 & 0.30 & $\begin{array}{l}0.014 \\
(0.02)\end{array}$ & 1416 & 0.16 \\
\hline Tier $1 /$ ta×h_liquid & $\begin{array}{l}0.584 * * * \\
(0.11)\end{array}$ & 958 & 0.60 & $\begin{array}{l}-0.044 \\
(0.34)\end{array}$ & 958 & 0.24 & $\begin{array}{l}0.037 * * \\
(0.02)\end{array}$ & 958 & 0.32 \\
\hline Tier 2/ta×h_liquid & $\begin{array}{l}5.645^{*} \\
(2.88)\end{array}$ & 946 & 0.42 & $\begin{array}{l}2.921 \\
(4.25)\end{array}$ & 946 & 0.20 & $\begin{array}{l}0.197 \\
(0.44)\end{array}$ & 946 & 0.09 \\
\hline Total capital/taxh_liquid & $\begin{array}{l}0.543^{* * * *} \\
(0.09)\end{array}$ & 1120 & 0.56 & $\begin{array}{l}0.138 \\
(0.29)\end{array}$ & 1120 & 0.26 & $\begin{array}{l}0.043 * * * \\
(0.01)\end{array}$ & 1120 & 0.31 \\
\hline Common equity/taxh_liquid & $\begin{array}{l}0.455^{* * * *} \\
(0.14)\end{array}$ & 1877 & 0.37 & $\begin{array}{l}0.266 \\
(0.24)\end{array}$ & 1877 & 0.27 & $\begin{array}{l}0.003 \\
(0.01)\end{array}$ & 1877 & 0.33 \\
\hline Tangible equity/taxh_liquid & $\begin{array}{l}0.448 * * * \\
(0.14)\end{array}$ & 1877 & 0.36 & $\begin{array}{l}0.193 \\
(0.25)\end{array}$ & 1877 & 0.26 & $\begin{array}{l}0.007 \\
(0.01)\end{array}$ & 1877 & 0.31 \\
\hline
\end{tabular}

Panel B: GCC vs. non-GCC countries

\begin{tabular}{|c|c|c|c|c|c|c|c|c|c|}
\hline \multirow[t]{2}{*}{ Variables } & \multicolumn{3}{|c|}{ LLRGLP } & \multicolumn{3}{|c|}{ CIRP } & \multicolumn{3}{|c|}{ EARTAP } \\
\hline & Coef. & $\mathrm{N}$ & $\mathrm{R} 2$ & Coef. & $\mathrm{N}$ & $\mathrm{R} 2$ & Coef. & $\mathrm{N}$ & $\mathrm{R} 2$ \\
\hline $\begin{array}{l}\text { Tier 1/rwa×GCC_dum } \\
\text { Tier 1/rwa×NGCC_dum }\end{array}$ & $\begin{array}{l}0.167 \\
(0.10) \\
0.073 \\
(0.08)\end{array}$ & 970 & 0.29 & $\begin{array}{l}-0.882 * * * \\
(0.31) \\
-0.144 \\
(0.15)\end{array}$ & 970 & 0.35 & $\begin{array}{l}0.062 * * * \\
(0.01) \\
0.037 * * * \\
(0.01)\end{array}$ & 970 & 0.21 \\
\hline $\begin{array}{l}\text { Tier 2/rwa×GCC_dum } \\
\text { Tier 2/rwa×NGCC_dum }\end{array}$ & $\begin{array}{l}0.419 * * \\
(0.18) \\
0.364 \\
(0.25)\end{array}$ & 965 & 0.28 & $\begin{array}{l}-1.625^{* * *} \\
(0.49) \\
1.823^{* * *} \\
(0.67)\end{array}$ & 965 & 0.25 & $\begin{array}{l}-0.024 \\
(0.03) \\
-0.155^{* * *} \\
(0.04)\end{array}$ & 965 & 0.14 \\
\hline $\begin{array}{l}\text { Total capital/rwa×GCC_dum } \\
\text { Total capital/rwa×NGCC_dum }\end{array}$ & $\begin{array}{l}0.227 * * \\
(0.09) \\
0.197 * * \\
(0.09)\end{array}$ & 1416 & 0.37 & $\begin{array}{l}-0.951 * * * \\
(0.13) \\
-0.335 * * \\
(0.13)\end{array}$ & 1416 & 0.38 & $\begin{array}{l}0.058 * * * \\
(0.00) \\
0.036 * * * \\
(0.01)\end{array}$ & 1416 & 0.18 \\
\hline $\begin{array}{l}\text { Tier 1/ta×GCC_dum } \\
\text { Tier 1/ta×NGCC_dum }\end{array}$ & $\begin{array}{l}0.511 * * * \\
(0.13) \\
0.502 * * * \\
(0.1)\end{array}$ & 958 & 0.56 & $\begin{array}{l}-1.226 * * * \\
(0.20) \\
-0.305 \\
(0.21)\end{array}$ & 958 & 0.33 & $\begin{array}{l}0.103 * * * \\
(0.01) \\
0.0861 * * * \\
(0.01)\end{array}$ & 958 & 0.31 \\
\hline $\begin{array}{l}\text { Tier 2/ta×GCC_dum } \\
\text { Tier 2/ta×NGCC_dum }\end{array}$ & $\begin{array}{l}0.794 * * * \\
(0.28) \\
0.899 * \\
(0.47)\end{array}$ & 946 & 0.39 & $\begin{array}{l}-1.847 * * * \\
(0.61) \\
3.387 * * * \\
(1.03)\end{array}$ & 946 & 0.24 & $\begin{array}{l}-0.005 \\
(0.05) \\
-0.135^{*} \\
(0.07)\end{array}$ & 946 & 0.08 \\
\hline $\begin{array}{l}\text { Total capital/ta×GCC_dum } \\
\text { Total capital/ta×NGCC_dum }\end{array}$ & $\begin{array}{l}0.466 * * * \\
(0.11) \\
0.495 * * * \\
(0.10)\end{array}$ & 1120 & 0.52 & $\begin{array}{l}-1.006^{* * *} \\
(0.18) \\
-0.15 \\
(0.21)\end{array}$ & 1120 & 0.33 & $\begin{array}{l}0.092 * * * \\
(0.01) \\
0.081 * * * \\
(0.01)\end{array}$ & 1120 & 0.29 \\
\hline $\begin{array}{l}\text { Common equity/taxGCC_dum } \\
\text { Common equity/ta×NGCC_dum }\end{array}$ & $\begin{array}{l}0.214 \\
(0.13) \\
0.229 \\
(0.15)\end{array}$ & 1877 & 0.33 & $\begin{array}{l}-1.33^{* * * *} \\
(0.16) \\
-0.35^{* *} \\
(0.14)\end{array}$ & 1877 & 0.32 & $\begin{array}{l}0.115 * * * \\
(0.01) \\
0.089 * * * \\
(0.00)\end{array}$ & 1877 & 0.32 \\
\hline $\begin{array}{l}\text { Tangible equity/ta×GCC_dum } \\
\text { Tangible equity/ta×NGCC_dum }\end{array}$ & $\begin{array}{l}0.221 * \\
(0.13) \\
0.236 \\
(0.15) \\
\end{array}$ & 1877 & 0.34 & $\begin{array}{l}-1.333 * * * \\
(0.14) \\
-0.4 * * * \\
(0.14) \\
\end{array}$ & 1877 & 0.33 & $\begin{array}{l}0.115 * * * \\
(0.01) \\
0.093 \\
(0.01) \\
\end{array}$ & 1877 & 0.34 \\
\hline \multicolumn{10}{|l|}{ Panel C: subprime vs. normal time } \\
\hline \multirow[t]{2}{*}{ Variables } & \multicolumn{3}{|c|}{ LLRGLP } & \multicolumn{3}{|c|}{ CIRP } & \multicolumn{3}{|c|}{ EARTAP } \\
\hline & Coef. & $\mathrm{N}$ & $\mathrm{R} 2$ & Coef. & $\mathrm{N}$ & $\mathrm{R} 2$ & Coef. & $\mathrm{N}$ & $\mathrm{R} 2$ \\
\hline $\begin{array}{l}\text { Tier } 1 / \text { rwaxcrisis } \\
\text { Tier } 1 / \text { rwa×normal }\end{array}$ & $\begin{array}{l}0.142 \\
(0.1) \\
0.112 \\
(0.08)\end{array}$ & 970 & 0.28 & $\begin{array}{l}-0.502 * * * \\
(0.17) \\
-0.589 * * * \\
(0.15)\end{array}$ & 970 & 0.23 & $\begin{array}{l}0.038 * * * \\
(0.01) \\
0.055^{* * *} \\
(0.01)\end{array}$ & 970 & 0.20 \\
\hline Tier $2 /$ rwaxcrisis & $\begin{array}{l}0.407 * \\
(0.24)\end{array}$ & 965 & 0.28 & $\begin{array}{l}-0.331 \\
(0.51)\end{array}$ & 965 & 0.20 & $\begin{array}{l}-0.151 * * * \\
(0.04)\end{array}$ & 965 & 0.13 \\
\hline Tier 2/rwa×normal & $\begin{array}{l}0.398 * * * \\
(0.15)\end{array}$ & & & $\begin{array}{l}-0.446 \\
(0.42)\end{array}$ & & & $\begin{array}{l}-0.051 \\
(0.03)\end{array}$ & & \\
\hline Total capital/rwa×crisis & $\begin{array}{l}0.224 * * \\
(0.08)\end{array}$ & 1416 & 0.37 & $\begin{array}{l}-0.55^{* * * *} \\
(0.14)\end{array}$ & 1416 & 0.30 & $\begin{array}{l}0.038 * * * \\
(0.01)\end{array}$ & 1416 & 0.16 \\
\hline Total capital/rwaxnormal & $\begin{array}{l}0.205 * * * \\
(0.08)\end{array}$ & & & $\begin{array}{l}-0.656^{* * * *} \\
(0.11)\end{array}$ & & & $\begin{array}{l}0.048 \text { *** } \\
(0.01)\end{array}$ & & \\
\hline Tier $1 /$ taxcrisis & $0.504 * * *$ & 958 & 0.56 & $-0.543 * * *$ & 958 & 0.23 & $0.092 * * *$ & 958 & 0.31 \\
\hline
\end{tabular}




\begin{tabular}{|c|c|c|c|c|c|c|c|c|c|}
\hline Tier $1 /$ ta $\times$ normal & \multicolumn{3}{|l|}{$\begin{array}{l}0.504 * * * \\
(0.09)\end{array}$} & \multicolumn{3}{|l|}{$\begin{array}{l}-0.533 * * * \\
(0.2)\end{array}$} & \multicolumn{3}{|l|}{$\begin{array}{l}0.09 * * * \\
(0.01)\end{array}$} \\
\hline Tier $2 /$ taxcrisis & $\begin{array}{l}0.656^{*} \\
(0.37)\end{array}$ & \multirow[t]{2}{*}{946} & \multirow[t]{2}{*}{0.39} & $\begin{array}{l}-0.453 \\
(0.66)\end{array}$ & \multirow[t]{2}{*}{946} & \multirow[t]{2}{*}{0.19} & $\begin{array}{l}-0.109^{*} \\
(0.06)\end{array}$ & \multirow[t]{2}{*}{946} & \multirow[t]{2}{*}{0.08} \\
\hline Tier 2/ta×normal & $\begin{array}{l}0.861 * * * \\
(0.27)\end{array}$ & & & $\begin{array}{l}-0.346 \\
(0.6)\end{array}$ & & & $\begin{array}{l}-0.027 \\
(0.05)\end{array}$ & & \\
\hline Total capital/taxcrisis & $\begin{array}{l}0.484 * * * \\
(0.11)\end{array}$ & 1120 & \multirow[t]{2}{*}{0.52} & $\begin{array}{l}-0.403 * * \\
(0.18)\end{array}$ & \multirow[t]{2}{*}{1120} & \multirow[t]{2}{*}{0.25} & $\begin{array}{l}0.082 * * * \\
(0.01)\end{array}$ & \multirow[t]{2}{*}{1120} & \multirow[t]{2}{*}{0.29} \\
\hline Total capital/ta×normal & \multicolumn{2}{|l|}{$\begin{array}{l}0.487 * * * \\
(0.09)\end{array}$} & & $\begin{array}{l}-0.484 * * * \\
(0.18)\end{array}$ & & & $\begin{array}{l}0.0857 * * * \\
(0.01)\end{array}$ & & \\
\hline Common equity/taxcrisis & $\begin{array}{l}0.235 \\
(0.17)\end{array}$ & 1877 & 0.33 & $\begin{array}{l}-0.488 * * * \\
(0.14)\end{array}$ & 1877 & 0.25 & $\begin{array}{l}0.085 * * * \\
(0.01)\end{array}$ & 1880 & 0.31 \\
\hline Common equity/ta×normal & $\begin{array}{l}0.224 \\
(0.14)\end{array}$ & & & $\begin{array}{l}-0.671 * * * \\
(0.13)\end{array}$ & & & $\begin{array}{l}0.099 * * * \\
(0.01)\end{array}$ & & \\
\hline Tangible equity/ta×crisis & $\begin{array}{l}0.257 \\
(0.17)\end{array}$ & 1877 & 0.34 & $\begin{array}{l}-0.594 * * * \\
(0.14)\end{array}$ & 1877 & 0.26 & $\begin{array}{l}0.094 * * * \\
(0.01)\end{array}$ & 1877 & 0.33 \\
\hline Tangible equity/ta×normal & $\begin{array}{l}0.228 \\
(0.14) \\
\end{array}$ & & & $\begin{array}{l}-0.731^{* * *} \\
(0.13) \\
\end{array}$ & & & $\begin{array}{l}0.101 * * * \\
(0.01)\end{array}$ & & \\
\hline Panel D: world governance indic & & & & & & & & & \\
\hline Variables & & LLRG & & & CIRP & & & EART & \\
\hline & Coef. & $\mathrm{N}$ & $\mathrm{R} 2$ & Coef. & $\mathrm{N}$ & $\mathrm{R} 2$ & Coef. & $\mathrm{N}$ & $\mathrm{R} 2$ \\
\hline Tier 1/rwa×GCCD×world_gov & $\begin{array}{l}0.257 \\
(0.26)\end{array}$ & 970 & 0.28 & $\begin{array}{l}-1.156^{* * * *} \\
(0.23)\end{array}$ & 970 & 0.26 & $\begin{array}{l}0.080 * * * \\
(0.01)\end{array}$ & 970 & 0.23 \\
\hline Tier 1/rwa×NGCCD×world_gov & $\begin{array}{l}0.128 \\
(0.13)\end{array}$ & & & $\begin{array}{l}-0.114 \\
(0.25)\end{array}$ & & & $\begin{array}{l}0.052 * * * \\
(0.02)\end{array}$ & & \\
\hline Tier 2/rwa×GCCD×world_gov & $\begin{array}{l}0.62 * * \\
(0.29)\end{array}$ & 956 & 0.27 & $\begin{array}{l}-2.191 * * * \\
(0.75)\end{array}$ & 956 & 0.24 & $\begin{array}{l}-0.041 \\
(0.05)\end{array}$ & 956 & 0.14 \\
\hline Tier 2/rwa×NGCCD×world_gov & $\begin{array}{l}0.608 \\
(0.42)\end{array}$ & & & $\begin{array}{l}3.21 * * * \\
(1.14)\end{array}$ & & & $\begin{array}{l}-0.255^{* * *} \\
(0.08)\end{array}$ & & \\
\hline Total capital/rwax & $0.312 * *$ & 1394 & 0.37 & $-1.296 * * *$ & 1394 & 0.36 & $0.08 * * *$ & 1394 & 0.17 \\
\hline GCCD×world_gov & $(0.14)$ & & & $(0.19)$ & & & $(0.01)$ & & \\
\hline Total capital/rwax & $0.322 * *$ & & & $-0.486 * *$ & & & $0.059 * * *$ & & \\
\hline NGCCD×world_gov & $(0.16)$ & & & $(0.23)$ & & & $(0.02)$ & & \\
\hline Tier 1/ta×GCCD×world_gov & $\begin{array}{l}0.75 * * * \\
(0.19)\end{array}$ & 949 & 0.57 & $\begin{array}{l}-1.757 * * * \\
(0.30)\end{array}$ & 949 & 0.31 & $\begin{array}{l}0.138 * * * \\
(0.02)\end{array}$ & 949 & 0.29 \\
\hline Tier 1/ta×NGCCD×world_gov & $\begin{array}{l}0.825 * * * \\
(0.16)\end{array}$ & & & $\begin{array}{l}-0.54 \\
(0.35)\end{array}$ & & & $\begin{array}{l}0.131 * * * \\
(0.02)\end{array}$ & & \\
\hline Tier 2/ta×GCCD×world_gov & $\begin{array}{l}1.17 * * * \\
(0.43)\end{array}$ & 937 & 0.39 & $\begin{array}{l}-2.518 * * * \\
(0.94)\end{array}$ & 937 & 0.24 & $\begin{array}{l}-0.022 \\
(0.07)\end{array}$ & 937 & 0.09 \\
\hline Tier $2 /$ taxNGCCDx & $1.489 *$ & & & $5.879 * * *$ & & & $-0.227 *$ & & \\
\hline GCCD×world_gov & $(0.77)$ & & & $(1.66)$ & & & $(0.12)$ & & \\
\hline Total capital/tax & $0.691 * * *$ & 1098 & 0.53 & $-1.483 * * *$ & 1098 & 0.33 & $0.127 * * *$ & 1098 & 0.28 \\
\hline GCCD×world_gov & $(0.16)$ & & & $(0.26)$ & & & $(0.02)$ & & \\
\hline Total capital/tax & $0.817 * * *$ & & & -0.311 & & & $0.127 * * *$ & & \\
\hline NGCCD×world_gov & $(0.16)$ & & & $(0.34)$ & & & $(0.02)$ & & \\
\hline Common equity/tax & $0.34^{*}$ & 1834 & 0.36 & $-1.86^{* * *}$ & 1834 & 0.32 & $0.162 * * *$ & 1834 & 0.30 \\
\hline GCCD×world_gov & $(0.19)$ & & & $(0.24)$ & & & $(0.02)$ & & \\
\hline Common equity/tax & $0.457^{*}$ & & & $-0.509 *$ & & & $0.142 * * *$ & & \\
\hline NGCCD×world_gov & $(0.25)$ & & & $(0.26)$ & & & $(0.02)$ & & \\
\hline Tangible equity/tax & $0.344^{*}$ & 1834 & 0.36 & $-1.855 * * *$ & 1834 & 0.33 & $0.161 * * *$ & 1834 & 0.32 \\
\hline GCCD×world_gov & $(0.18)$ & & & $(0.22)$ & & & $(0.01)$ & & \\
\hline Tangible equity/tax & 0.463 & & & $-0.581 * *$ & & & $0.148 * * *$ & & \\
\hline NGCCD×world_gov & $(0.25)$ & & & $(0.26)$ & & & $(0.02)$ & & \\
\hline
\end{tabular}

(Continued)

Notes: See Appendix A.1 for the variables' definitions. The dependent variables are the bank loan loss reserves to gross loans (LLRGLP), the bank cost to income ratio (CIRP) and the bank earnings to assets (EARTAP). In the three models, we only employ the variables of interest and the coefficients of the interaction between capital and highly liquid banks (h_liquid) (Model A) and crisis period (Model B) to save space. The estimation is based on OLS regressions. Standard errors are clustered at the bank level and reported in parentheses below their coefficient estimates.

* Statistical significance at the $10 \%$ level.

$* *$ Statistical significance at the 5\% level.

$* * *$ Statistical significance at the $1 \%$ level. 
Table 7

Bank capital, risk and performance: controlling for the Arab Spring

Panel A: controlling for the Arab Spring

\begin{tabular}{|c|c|c|c|c|c|c|c|c|c|c|c|c|}
\hline & \multicolumn{4}{|c|}{ LLRGLP } & \multicolumn{4}{|c|}{ CIRP } & \multicolumn{4}{|c|}{ EARTAP } \\
\hline & [1] & [2] & {$[3]$} & [4] & {$[5]$} & [6] & [7] & {$[8]$} & [9] & {$[10]$} & [11] & {$[12]$} \\
\hline & $\mathrm{X} 1=\mathrm{PC} 1$ & $\mathrm{X} 2=\mathrm{PC} 2$ & $\mathrm{X} 3=\mathrm{PC} 3$ & $\mathrm{X} 4=\mathrm{PC} 4$ & $\mathrm{X} 1=\mathrm{PC} 1$ & $\mathrm{X} 2=\mathrm{PC} 2$ & $\mathrm{X} 3=\mathrm{PC} 3$ & $\mathrm{X} 4=\mathrm{PC} 4$ & $\mathrm{X} 1=\mathrm{PC} 1$ & $\mathrm{X} 2=\mathrm{PC} 2$ & $\mathrm{X} 3=\mathrm{PC} 3$ & $\mathrm{X} 4=\mathrm{PC} 4$ \\
\hline GCC_dum*AS_1 & 0.346 & 0.782 & 0.325 & -0.055 & -0.431 & -1.795 & -0.385 & -0.933 & $-0.339 * *$ & -0.132 & $-0.341 * *$ & $-0.345 * *$ \\
\hline & $(0.55)$ & $(0.57)$ & $(0.55)$ & $(0.65)$ & (2.49) & $(2.66)$ & $(2.48)$ & $(2.50)$ & $(0.13)$ & $(0.15)$ & $(0.13)$ & $(0.13)$ \\
\hline NGCC_dum*AS_1 & -0.252 & -0.003 & -0.233 & -1.157 & $5.028 * * *$ & $4.907 * *$ & $4.971 * * *$ & $6.268 * * *$ & -0.181 & -0.223 & -0.174 & $-0.35^{* *}$ \\
\hline & $(1.06)$ & $(1.23)$ & $(1.06)$ & $(0.77)$ & $(1.87)$ & $(2.05)$ & $(1.87)$ & $(2.37)$ & $(0.11)$ & $(0.16)$ & $(0.11)$ & $(0.15)$ \\
\hline PC1_basel2_rwa & $\begin{array}{l}0.764 * \\
(0.4)\end{array}$ & & & & $\begin{array}{l}-2.047 * * * \\
(0.59)\end{array}$ & & & & $\begin{array}{l}0.255^{* * * *} \\
(0.04)\end{array}$ & & & \\
\hline PC2_basel2_tier2 & & $\begin{array}{l}0.544^{* *} \\
(0.22)\end{array}$ & & & & $\begin{array}{l}-0.741 \\
(0.58)\end{array}$ & & & & $\begin{array}{l}-0.038 \\
(0.04)\end{array}$ & & \\
\hline PC3_basel2_extier2 & & & $\begin{array}{l}0.78^{*} \\
(0.4)\end{array}$ & & & & $\begin{array}{l}-2.077 \text { *** } \\
(0.59)\end{array}$ & & & & $\begin{array}{l}0.255^{* * *} \\
(0.04)\end{array}$ & \\
\hline PC4_trad_capital & & & & $\begin{array}{l}2.292 * * * * \\
(0.49)\end{array}$ & & & & $\begin{array}{l}-2.625 * * * \\
(0.85)\end{array}$ & & & & $\begin{array}{l}0.453 * * * \\
(0.05)\end{array}$ \\
\hline Constant & $\begin{array}{l}21.068^{* * * *} \\
(4.87)\end{array}$ & $\begin{array}{l}28.983 * * * \\
(5.95)\end{array}$ & $\begin{array}{l}20.998 * * * * \\
(4.87)\end{array}$ & $\begin{array}{l}25.387 * * * \\
(6.04)\end{array}$ & $\begin{array}{l}118.099 \text { *** } \\
(14.08)\end{array}$ & $\begin{array}{l}108.037 * * * \\
(15.03)\end{array}$ & $\begin{array}{l}117.908 \text { *** } \\
(14.10)\end{array}$ & $\begin{array}{l}119.017 \text { *** } \\
(13.38)\end{array}$ & $\begin{array}{l}-1.622 * * \\
(0.11)\end{array}$ & $\begin{array}{l}-0.86 \\
(0.76)\end{array}$ & $\begin{array}{l}-1.585 * * \\
(0.70)\end{array}$ & $\begin{array}{l}-1.38 * * \\
(0.66)\end{array}$ \\
\hline Bank_control & Yes & Yes & Yes & Yes & Yes & Yes & Yes & Yes & Yes & Yes & Yes & Yes \\
\hline Observations & 822 & 822 & 822 & 932 & 822 & 822 & 822 & 932 & 822 & 822 & 822 & 932 \\
\hline $\mathrm{R} 2$ & 0.32 & 0.29 & 0.32 & 0.53 & 0.23 & 0.19 & 0.23 & 0.24 & 0.27 & 0.12 & 0.27 & 0.34 \\
\hline
\end{tabular}

Panel B: Controlling for the Arab Spring using alternative risk and performance measures

\begin{tabular}{|c|c|c|c|c|c|c|c|c|c|c|c|c|}
\hline \multirow[t]{2}{*}{ 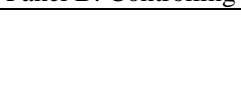 } & \multicolumn{4}{|c|}{ NPLGLP } & \multicolumn{4}{|c|}{$\begin{array}{l}\text { NIMP } \\
\end{array}$} & \multicolumn{4}{|c|}{ EARGLP } \\
\hline & $\begin{array}{c}{[1]} \\
\mathrm{X} 1=\mathrm{PC} 1\end{array}$ & $\begin{array}{c}{[2]} \\
\mathrm{X} 2=\mathrm{PC} 2\end{array}$ & $\begin{array}{c}{[3]} \\
\mathrm{X} 3=\mathrm{PC} 3\end{array}$ & $\begin{array}{c}{[4]} \\
\mathrm{X} 4=\mathrm{PC} 4\end{array}$ & $\begin{array}{c}5] \\
\mathrm{X} 1=\mathrm{PC} 1\end{array}$ & $\begin{array}{c}{[6]} \\
\mathrm{X} 2=\mathrm{PC} 2\end{array}$ & $\begin{array}{c}{[7]} \\
\mathrm{X} 3=\mathrm{PC} 3\end{array}$ & $\begin{array}{c}8] \\
\mathrm{X} 4=\mathrm{PC} 4\end{array}$ & $\begin{array}{c}9] \\
\mathrm{X} 1=\mathrm{PC} 1\end{array}$ & $\begin{array}{c}{[10]} \\
\mathrm{X} 2=\mathrm{PC} 2\end{array}$ & $\begin{array}{c}{[11]} \\
\mathrm{X} 3=\mathrm{PC} 3\end{array}$ & $\begin{array}{c}{[12]} \\
\mathrm{X} 4=\mathrm{PC} 4\end{array}$ \\
\hline GCC_dum*AS_1 & $\begin{array}{l}2.151^{*} \\
(1.25)\end{array}$ & $\begin{array}{l}2.696^{*} \\
(1.39)\end{array}$ & $\begin{array}{l}2.125^{*} \\
(1.25)\end{array}$ & $\begin{array}{l}1.291 \\
(1.32)\end{array}$ & $\begin{array}{l}-0.68 * * * \\
(0.16)\end{array}$ & $\begin{array}{l}-0.51 * * * \\
(0.17)\end{array}$ & $\begin{array}{l}-0.68^{* * * *} \\
(0.16)\end{array}$ & $\begin{array}{l}-0.743 * * * \\
(0.17)\end{array}$ & $\begin{array}{l}-1.118^{* * * *} \\
(0.39)\end{array}$ & $\begin{array}{l}-0.227 \\
(0.30)\end{array}$ & $\begin{array}{l}-1.133 * * * \\
(0.4)\end{array}$ & $\begin{array}{l}-1.702 * * \\
(1.37)\end{array}$ \\
\hline NGCC_dum*AS_1 & $\begin{array}{l}1.138 \\
(1.51)\end{array}$ & $\begin{array}{l}1.442 \\
(1.75)\end{array}$ & $\begin{array}{l}1.162 \\
(1.51)\end{array}$ & $\begin{array}{l}-1.029 \\
(1.07)\end{array}$ & $\begin{array}{l}0.394 * * \\
(0.17)\end{array}$ & $\begin{array}{l}0.324 \\
(0.2)\end{array}$ & $\begin{array}{l}0.398 * * \\
(0.17)\end{array}$ & $\begin{array}{l}0.242 \\
(0.18)\end{array}$ & $\begin{array}{l}0.621 \\
(0.86)\end{array}$ & $\begin{array}{l}0.525 \\
(1.2)\end{array}$ & $\begin{array}{l}0.651 \\
(0.87)\end{array}$ & $\begin{array}{l}0.021 \\
(1.37)\end{array}$ \\
\hline PC1_basel2_rwa & $\begin{array}{l}0.938 \\
(0.58)\end{array}$ & & & & $\begin{array}{l}0.179 * * * \\
(0.05)\end{array}$ & & & & $\begin{array}{l}1.18^{* * *} \\
(0.38)\end{array}$ & & & \\
\hline PC2_basel2_tier2 & & $\begin{array}{l}0.65^{* *} \\
(0.32)\end{array}$ & & & & $\begin{array}{l}-0.117 \text { ** } \\
(0.05)\end{array}$ & & & & $\begin{array}{l}0.054 \\
(0.13)\end{array}$ & & \\
\hline PC3_basel2_extier2 & & & $\begin{array}{l}0.958 \\
(0.58)\end{array}$ & & & & $\begin{array}{l}0.177 * * * \\
(0.05)\end{array}$ & & & & $\begin{array}{l}1.182 * * * \\
(0.38)\end{array}$ & \\
\hline PC4_trad_capital & & & & $\begin{array}{l}3.297 * * * \\
(0.73)\end{array}$ & & & & $\begin{array}{l}0.391 * * * \\
(0.09)\end{array}$ & & & & $\begin{array}{l}3.391 * * * \\
(0.71)\end{array}$ \\
\hline Constant & $\begin{array}{l}44.636 * * * \\
(7.26)\end{array}$ & $\begin{array}{l}54.318 * * * \\
(1.75)\end{array}$ & $\begin{array}{l}44.533 * * * \\
(7.23)\end{array}$ & $\begin{array}{l}49.312^{* * *} \\
(8.18)\end{array}$ & $\begin{array}{l}4.737 * * * \\
(1.02)\end{array}$ & $\begin{array}{l}4.929 * * * \\
(1.04)\end{array}$ & $\begin{array}{l}4.772^{* * * *} \\
(1.02)\end{array}$ & $\begin{array}{l}4.113 * * * \\
(0.99)\end{array}$ & $\begin{array}{l}-3.294 \\
(2.93)\end{array}$ & $\begin{array}{l}1.088 \\
(2.53)\end{array}$ & $\begin{array}{l}-3.133 \\
(2.91)\end{array}$ & $\begin{array}{l}-6.469 \\
(4.28)\end{array}$ \\
\hline Bank_control & Yes & Yes & Yes & Yes & Yes & Yes & Yes & Yes & Yes & Yes & Yes & Yes \\
\hline Observations & 804 & 804 & 804 & 901 & 822 & 822 & 822 & 932 & 822 & 822 & 822 & 932 \\
\hline R2 & 0.37 & 0.35 & 0.37 & 0.57 & 0.33 & 0.3 & 0.33 & 0.35 & 0.34 & 0.11 & 0.34 & 0.60 \\
\hline
\end{tabular}

Notes: See Appendix A.1 for the variables' definitions. The estimation is based on OLS regressions. Standard errors are clustered at the bank level and reported in parentheses below their coefficient estimates.

* Statistical significance at the $10 \%$ level.

** Statistical significance at the $5 \%$ level.

*** Statistical significance at the $1 \%$ level. 
Table 8

Bank capital, risk and performance: the impact of the Arab Spring

Panel A: bank capital, risk and performance

\begin{tabular}{|c|c|c|c|c|c|c|c|c|c|}
\hline \multirow[t]{2}{*}{ Variables } & \multicolumn{3}{|c|}{ LLRGLP } & \multicolumn{3}{|c|}{ CIRP } & \multicolumn{3}{|c|}{ EARTAP } \\
\hline & Coef. & $\mathrm{N}$ & R2 & Coef. & $\mathrm{N}$ & $\mathrm{R} 2$ & Coef. & $\mathrm{N}$ & $\mathrm{R} 2$ \\
\hline $\begin{array}{l}\mathrm{PC} 1 \text { basel2_rwa } \times \mathrm{GCC} \text { _dum } \times \mathrm{AS} \_1 \\
\mathrm{PC} 1 \text { basel2_rwa } \times \mathrm{NGCC} \text { _dum } \times \mathrm{AS} \_1\end{array}$ & $\begin{array}{l}0.842 * * \\
(0.41) \\
2.044 * * * \\
(0.50)\end{array}$ & 822 & 0.33 & $\begin{array}{l}-2.786 \\
(2.07) \\
-2.117 * * * \\
(0.49)\end{array}$ & 822 & 0.19 & $\begin{array}{l}0.202 \\
(0.13) \\
0.254 * * * \\
(0.05\end{array}$ & 822 & 0.14 \\
\hline $\begin{array}{l}\text { PC3_basel2_extier2 } \times \text { GCC_dum } \times \text { AS_1 } \\
\text { PC3_basel2_extier } 2 \times N G C C \text { dum } \times \text { AS_1 }\end{array}$ & $\begin{array}{l}0.838^{* *} \\
(0.42) \\
2.039^{* * *} \\
(0.51)\end{array}$ & 822 & 0.33 & $\begin{array}{l}-2.823 \\
(2.07) \\
-2.109 * * * \\
(0.49)\end{array}$ & 822 & 0.19 & $\begin{array}{l}0.2 \\
(0.13) \\
0.255^{* * *} \\
(0.05)\end{array}$ & 822 & 0.14 \\
\hline
\end{tabular}

Panel B: alternative measures of bank risk and performance

\begin{tabular}{|c|c|c|c|c|c|c|c|c|c|}
\hline \multirow[t]{2}{*}{ Variables } & \multicolumn{3}{|c|}{ NPLGLP } & \multicolumn{3}{|c|}{ NIMP } & \multicolumn{3}{|c|}{ EARGLP } \\
\hline & Coef. & $\mathrm{N}$ & $\mathrm{R} 2$ & Coef. & $\mathrm{N}$ & $\mathrm{R} 2$ & Coef. & $\mathrm{N}$ & $\mathrm{R} 2$ \\
\hline PC1_basel2_rwa $\times$ GCC_dum $\times$ AS_1 & $\begin{array}{l}2.601 * * \\
(1.13)\end{array}$ & 804 & 0.38 & $\begin{array}{l}0.082 \\
(0.17)\end{array}$ & 804 & 0.27 & $\begin{array}{l}0.082 \\
(0.45)\end{array}$ & 804 & 0.29 \\
\hline PC1_basel2_rwa $\times$ NGCC_dum $\times$ AS_1 & $\begin{array}{l}2.844 * * * \\
(0.79)\end{array}$ & & & $\begin{array}{l}0.231 \text { *** } \\
(0.04)\end{array}$ & & & $\begin{array}{l}2.813 * * \\
(0.61)\end{array}$ & & \\
\hline PC3_basel2_extier $2 \times$ GCC_dum $\times$ AS_1 & $\begin{array}{l}2.575^{* *} \\
(1.14)\end{array}$ & 804 & 0.38 & $\begin{array}{l}0.078 \\
(0.18)\end{array}$ & 804 & 0.27 & $\begin{array}{l}0.082 \\
(0.45)\end{array}$ & 804 & 0.29 \\
\hline PC3_basel2_extier $2 \times N G C C \_d u m \times A S \_1$ & $\begin{array}{l}2.832 * * * \\
(0.80)\end{array}$ & & & $\begin{array}{l}0.231 \text { *** } \\
(0.04)\end{array}$ & & & $\begin{array}{l}2.805 * * \\
(0.61)\end{array}$ & & \\
\hline
\end{tabular}

Notes: See Appendix A.1 for the variables' definitions. The estimation is based on OLS regressions. Standard errors are clustered at the bank level and reported in parentheses below their coefficient estimates.

* Statistical significance at the $10 \%$ level.

** Statistical significance at the $5 \%$ level.

*** Statistical significance at the $1 \%$ level. 
Table 9

Bank capital, risk and performance: one-year lag

\begin{tabular}{|c|c|c|c|c|c|c|c|c|c|}
\hline \multirow[t]{2}{*}{ Variables } & \multicolumn{3}{|c|}{ LLRGLP } & \multicolumn{3}{|c|}{ CIRP } & \multicolumn{3}{|c|}{ EARTAP } \\
\hline & Coef. & $\mathrm{N}$ & $\mathrm{R} 2$ & Coef. & $\mathrm{N}$ & $\mathrm{R} 2$ & Coef. & $\mathrm{N}$ & R2 \\
\hline Tier 1/rwa_1 & $\begin{array}{l}0.04 \\
(0.0833)\end{array}$ & 895 & 0.2712 & $\begin{array}{l}-0.433 * * * \\
(0.1468)\end{array}$ & 895 & 0.2082 & $\begin{array}{l}0.035 * * * \\
(0.009)\end{array}$ & 895 & 0.1494 \\
\hline Tier 2/rwa_1 & $\begin{array}{l}0.457 * * * \\
(0.1675)\end{array}$ & 891 & 0.2847 & $\begin{array}{l}-0.586 \\
(0.4071)\end{array}$ & 891 & 0.1887 & $\begin{array}{l}-0.047 \\
(0.0331)\end{array}$ & 891 & 0.1181 \\
\hline Total capital/rwa_1 & $\begin{array}{l}0.168 * * \\
(0.079)\end{array}$ & 1305 & 0.3689 & $\begin{array}{l}-0.489 * * * \\
(0.1144)\end{array}$ & 1305 & 0.2887 & $\begin{array}{l}0.035 \text { *** } \\
(0.0098)\end{array}$ & 1305 & 0.1405 \\
\hline Tier 1/ta_1 & $\begin{array}{l}0.477 * * * \\
(0.0983)\end{array}$ & 862 & 0.5585 & $\begin{array}{l}-0.326 \\
(0.2026)\end{array}$ & 862 & 0.2115 & $\begin{array}{l}0.064 * * * \\
(0.011)\end{array}$ & 862 & 0.2032 \\
\hline Tier 2/ta_1 & $\begin{array}{l}0.862 * * * \\
(0.2864)\end{array}$ & 846 & 0.3981 & $\begin{array}{l}-0.164 \\
(0.6211)\end{array}$ & 846 & 0.1903 & $\begin{array}{l}-0.043 \\
(0.0446)\end{array}$ & 846 & 0.0752 \\
\hline Total capital/ta_1 & $\begin{array}{l}0.498 * * * \\
(0.0907)\end{array}$ & 1014 & 0.5388 & $\begin{array}{l}-0.315 \\
(0.1901)\end{array}$ & 1014 & 0.2460 & $\begin{array}{l}0.065 * * * \\
(0.0109)\end{array}$ & 1014 & 0.2168 \\
\hline Common equity/ta_1 & $\begin{array}{l}0.217 \\
(0.1482)\end{array}$ & 1769 & 0.3327 & $\begin{array}{l}-0.533 * * * \\
(0.1409)\end{array}$ & 1769 & 0.2485 & $\begin{array}{l}0.077 * * * \\
(0.0099)\end{array}$ & 1771 & 0.2388 \\
\hline Tangible equity/ta_1 & $\begin{array}{l}0.229 \\
(0.1467) \\
\end{array}$ & 1769 & 0.3351 & $\begin{array}{l}-0.607 * * * \\
(0.1418)\end{array}$ & 1877 & 0.2581 & $\begin{array}{l}0.081 * * * \\
(0.0094)\end{array}$ & 1771 & 0.2388 \\
\hline
\end{tabular}

Panel B: one-year lag of capital ratios using alternative risk and performance measures

\begin{tabular}{|c|c|c|c|c|c|c|c|c|c|}
\hline \multirow[t]{2}{*}{ Variables } & \multicolumn{3}{|c|}{ NPLGLP } & \multicolumn{3}{|c|}{ NIMP } & \multicolumn{3}{|c|}{ EARGLP } \\
\hline & Coef. & $\mathrm{N}$ & $\mathrm{R} 2$ & Coef. & $\mathrm{N}$ & $\mathrm{R} 2$ & Coef. & $\mathrm{N}$ & $\mathrm{R} 2$ \\
\hline Tier 1/rwa_1 & $\begin{array}{l}0.086 \\
(0.12)\end{array}$ & 873 & 0.32 & $\begin{array}{l}0.026^{*} \\
(0.01)\end{array}$ & 895 & 0.29 & $\begin{array}{l}0.069 \\
(0.06)\end{array}$ & 895 & 0.16 \\
\hline Tier 2/rwa_1 & $\begin{array}{l}0.495^{* *} \\
(0.23)\end{array}$ & 869 & 0.33 & $\begin{array}{l}-0.095^{* * * *} \\
(0.03)\end{array}$ & 891 & 0.29 & $\begin{array}{l}-0.221 \\
(0.15)\end{array}$ & 891 & 0.16 \\
\hline Total capital/rwa_1 & $\begin{array}{l}0.206 \\
(0.13)\end{array}$ & 1218 & 0.36 & $\begin{array}{l}0.026 * * \\
(0.01)\end{array}$ & 1305 & 0.23 & $\begin{array}{l}0.176^{*} \\
(0.09)\end{array}$ & 1305 & 0.21 \\
\hline Tier 1/ta_1 & $\begin{array}{l}0.705 * * * \\
(0.14)\end{array}$ & 840 & 0.60 & $\begin{array}{l}0.058 * * * \\
(0.01)\end{array}$ & 862 & 0.33 & $\begin{array}{l}0.598 * * * \\
(0.11)\end{array}$ & 862 & 0.57 \\
\hline Tier 2/ta_1 & $\begin{array}{l}0.964 * * \\
(0.40)\end{array}$ & 824 & 0.43 & $\begin{array}{l}-0.14 * * \\
(0.06)\end{array}$ & 846 & 0.28 & $\begin{array}{l}-0.181 \\
(0.24)\end{array}$ & 846 & 0.35 \\
\hline Total capital/ta_1 & $\begin{array}{l}0.683 * * * \\
(0.15)\end{array}$ & 979 & 0.53 & $\begin{array}{l}0.059 * * * \\
(0.02)\end{array}$ & 1014 & 0.31 & $\begin{array}{l}0.621 \text { *** } \\
(0.12)\end{array}$ & 1014 & 0.52 \\
\hline Common equity/ta_1 & $\begin{array}{l}0.436 * \\
(0.25)\end{array}$ & 1423 & 0.36 & $\begin{array}{l}0.097 * * * \\
(0.02)\end{array}$ & 1771 & 0.36 & $\begin{array}{l}0.534 * * * \\
(0.15)\end{array}$ & 1771 & 0.36 \\
\hline Tangible equity/ta_1 & $\begin{array}{l}0.437 * \\
(0.26)\end{array}$ & 1423 & 0.36 & $\begin{array}{l}0.094 * * * \\
(0.02)\end{array}$ & 1771 & 0.35 & $\begin{array}{l}0.539 * * * \\
(0.15)\end{array}$ & 1771 & 0.36 \\
\hline
\end{tabular}

Notes: See Appendix A.1 for the variables' definitions. The estimation is based on OLS regressions. Standard errors are clustered at the bank level and reported in parentheses below their coefficient estimates.

* Statistical significance at the $10 \%$ level.

** Statistical significance at the $5 \%$ level.

*** Statistical significance at the $1 \%$ level. 
Table 10

Controlling for endogeneity: an IV approach

Panel A: using two stage least squares (2sls)

\begin{tabular}{|c|c|c|c|c|c|c|c|c|c|c|c|c|}
\hline \multirow[t]{2}{*}{ Variables } & \multicolumn{4}{|c|}{ LLRGLP } & \multicolumn{4}{|c|}{ CIRP } & \multicolumn{4}{|c|}{ EARTAP } \\
\hline & Coef. & $\mathrm{N}$ & Chi2 & $\mathrm{F}$ & Coef. & $\mathrm{N}$ & Chi2 & $\mathrm{F}$ & Coef. & $\mathrm{N}$ & Chi2 & $\mathrm{F}$ \\
\hline Tier 2/rwa & $\begin{array}{l}9.5 \\
(11.6485)\end{array}$ & 965 & $15.34 * *$ & 0.69 & $\begin{array}{l}-4.95 \\
(7.2755)\end{array}$ & 965 & 3.64 & 0.49 & $\begin{array}{l}3.73 \\
(5.6119)\end{array}$ & 965 & 2.76 & 0.49 \\
\hline Total capital/rwa & $\begin{array}{l}1.262^{*} \\
(0.7414)\end{array}$ & 1416 & $65.26 * * *$ & $2.93 *$ & $\begin{array}{l}-3.127 * * \\
(1.3266)\end{array}$ & 1416 & $39.05^{* * * *}$ & $4.43 * * *$ & $\begin{array}{l}0.253 * * \\
(0.115)\end{array}$ & 1416 & $11.01 *$ & $4.43 * *$ \\
\hline Tier $1 /$ ta & $\begin{array}{l}0.569 * * * \\
(0.1563)\end{array}$ & 958 & $185.76^{* * * *}$ & $8.4 * * *$ & $\begin{array}{l}-1.656 * * * \\
(0.5708)\end{array}$ & 958 & $46.75^{* * * *}$ & 17.29 **** & $\begin{array}{l}0.127 * * * \\
(0.028)\end{array}$ & 958 & $62.29 * * *$ & $17.29^{* * * *}$ \\
\hline Total capital/ta & $\begin{array}{l}0.61 * * * \\
(0.1482)\end{array}$ & 1120 & $177.89 * * *$ & $11.79 * * *$ & $\begin{array}{l}-1.643 * * * \\
(0.5575)\end{array}$ & 1120 & $58.72 * * *$ & 27.03 **** & $\begin{array}{l}0.123 * * * \\
(0.0286)\end{array}$ & 1120 & $71.28 * * *$ & $27.04 * * *$ \\
\hline $\begin{array}{l}\text { Common } \\
\text { equity/ta }\end{array}$ & $\begin{array}{l}0.895 * * \\
(0.3734)\end{array}$ & 1877 & $139.95 * * *$ & $6.09 * *$ & $\begin{array}{l}-2.611 * * * \\
(0.8684)\end{array}$ & 1877 & $70.26 * * *$ & 10.83 **** & $\begin{array}{l}0.184 * * * \\
(0.0402)\end{array}$ & 1880 & $53.65^{* * * *}$ & $10.69^{* * * *}$ \\
\hline $\begin{array}{l}\text { Tangible } \\
\text { equity/ta }\end{array}$ & $\begin{array}{l}0.7^{* *} \\
(0.2754)\end{array}$ & 1877 & $155.29 * * *$ & $10.4^{* * * *}$ & $\begin{array}{l}-2.05^{* * *} \\
(0.583)\end{array}$ & 1877 & $81.85^{* * * *}$ & $17.76^{* * * *}$ & $\begin{array}{l}0.144 * * * \\
(0.0266)\end{array}$ & 1880 & $67.88^{* * * *}$ & $17.59^{* * * *}$ \\
\hline
\end{tabular}

Panel B: using limited information maximum likelihood (liml)

\begin{tabular}{|c|c|c|c|c|c|c|c|c|c|c|c|c|}
\hline Variables & \multicolumn{4}{|c|}{ LLRGLP } & \multicolumn{4}{|c|}{ CIRP } & \multicolumn{4}{|c|}{ EARTAP } \\
\hline Tier 1/rwa & $\begin{array}{l}1.01 * * \\
(0.4057)\end{array}$ & 970 & $81.76^{* * *}$ & $13.46^{* * * *}$ & $\begin{array}{l}-3.52^{* * * *} \\
(0.8488)\end{array}$ & 970 & $72.81 * * *$ & $22.68^{* * * *}$ & $\begin{array}{l}0.26 * * * \\
(0.0611)\end{array}$ & 970 & $56.64 * * *$ & $22.68^{* * *}$ \\
\hline Tier 2/rwa & $\begin{array}{l}9.5 \\
(7.7061)\end{array}$ & 965 & $31.17 * * *$ & 1.66 & $\begin{array}{l}-4.95 \\
(4.4442)\end{array}$ & 965 & 9.43 & 1.26 & $\begin{array}{l}3.73 \\
(3.4865)\end{array}$ & 965 & 5.08 & 1.26 \\
\hline Total capital/rwa & $\begin{array}{l}1.262 * \\
(0.4058)\end{array}$ & 1416 & $180.28 * * *$ & $12.73 * * *$ & $\begin{array}{l}-3.127 * * \\
(0.7254)\end{array}$ & 1416 & $139.13 * * *$ & $19.32 * * *$ & $\begin{array}{l}0.253 * * \\
(0.0582)\end{array}$ & 1416 & $49.33 * * *$ & $19.32 * * *$ \\
\hline Tier $1 /$ ta & $\begin{array}{l}0.569 * * * \\
(0.0897)\end{array}$ & 958 & $632.72 * * *$ & $48.68 * * *$ & $\begin{array}{l}-1.656^{* * * *} \\
(0.3369)\end{array}$ & 958 & $142.79 * * *$ & $79.99 * * *$ & $\begin{array}{l}0.127 * * * \\
(0.018)\end{array}$ & 958 & $159.31 * * *$ & $79.99 * * *$ \\
\hline $\begin{array}{l}\text { Common } \\
\text { equity/ta }\end{array}$ & $\begin{array}{l}0.895 * * * \\
(0.1996)\end{array}$ & 1877 & $427.02 * * *$ & $28.82 * * *$ & $\begin{array}{l}-2.611^{* * *} \\
(0.4546)\end{array}$ & 1877 & $262.82 * * *$ & $47.83 * * * *$ & $\begin{array}{l}0.184 * * * \\
(0.0249)\end{array}$ & 1880 & $147.85 * * *$ & $47.06^{* * *}$ \\
\hline $\begin{array}{l}\text { Tangible } \\
\text { equity/ta }\end{array}$ & $\begin{array}{l}0.7 * * * \\
(0.1431)\end{array}$ & 1877 & $461.71 * * *$ & $48.83 * * *$ & $\begin{array}{l}-2.05 * * * \\
(0.583)\end{array}$ & 1877 & $323.46 * * *$ & $79.05 * * *$ & $\begin{array}{l}0.144 * * * \\
(0.0173)\end{array}$ & 1880 & $184.41 * * *$ & $78.00 * * *$ \\
\hline \multicolumn{13}{|c|}{ Panel C: using generalized method of moments (GMM) } \\
\hline
\end{tabular}




\begin{tabular}{|c|c|c|c|c|c|c|c|c|c|c|c|c|}
\hline Total capital/rwa & $\begin{array}{l}(28.3619) \\
1.262 \\
(1.7521)\end{array}$ & 1416 & $168.13^{* * * *}$ & $28.9 * * *$ & $\begin{array}{l}(4.3214) \\
-3.127 * * \\
(0.9858)\end{array}$ & 1416 & $88.33 * * *$ & $30.1^{* * * *}$ & $\begin{array}{l}(11.5332) \\
0.253 * * \\
(0.0539)\end{array}$ & 1416 & $56.94 * * *$ & $30.1 * * *$ \\
\hline Tier $1 /$ ta & $\begin{array}{l}0.569 * * * \\
(0.0832)\end{array}$ & 958 & $733.46 * * *$ & $129.78 * * *$ & $\begin{array}{l}-1.656 * * * \\
(0.3719)\end{array}$ & 958 & $200.24 * * *$ & $107.43^{* * *}$ & $\begin{array}{l}0.127 * * * \\
(0.0169)\end{array}$ & 958 & $161.62 * * *$ & $107.43^{* * *}$ \\
\hline Total capital/ta & $\begin{array}{l}0.61 * * * \\
(0.098)\end{array}$ & 1120 & $564.75^{* * *}$ & 172.26 *** & $\begin{array}{l}-1.643 * * * \\
(0.2943)\end{array}$ & 1120 & $279.77 * * *$ & $131.56^{* * *}$ & $\begin{array}{l}0.123 * * * \\
(0.0183)\end{array}$ & 1120 & $193.42 * * *$ & $131.56^{* * *}$ \\
\hline $\begin{array}{l}\text { Common } \\
\text { equity/ta }\end{array}$ & $\begin{array}{l}0.895 * * \\
(0.2011)\end{array}$ & 1877 & $420.2 * * *$ & $66.87 * * *$ & $\begin{array}{l}-2.611 * * * \\
(0.4762)\end{array}$ & 1877 & $213.74 * * *$ & $79.96 * * *$ & $\begin{array}{l}0.184 * * * \\
(0.0234)\end{array}$ & 1880 & $121.14 * * *$ & $78.77 * * *$ \\
\hline
\end{tabular}

Notes: See Appendix A.1 for the variables' definitions. This table presents the results after using the Instrumental Variables (IV) approach to control for endogeneity. The results only present the second stage regression. In Panel A, we use a 2 Stage Least Squares (2SLS) estimation technique. In Panel B, we use Limited Information Maximum Likelihood (LIML) estimation technique. In Panel C, we employ Generalized Method of Moments (GMM) estimation technique. Standard errors are clustered at the bank level in Panel A, robust in Panel B, and bootstrapped based on a 100 resampling in Panel C. Standard errors are reported in parentheses below their coefficient estimates.

* Statistical significance at the $10 \%$ level.

** Statistical significance at the $5 \%$ level.

*** Statistical significance at the $1 \%$ level. 
Table 11

Alternative estimation techniques

Panel A: bootstrapped standard errors based on a resample of 100

\begin{tabular}{|c|c|c|c|c|c|c|c|c|c|}
\hline \multirow[t]{2}{*}{ Variables } & \multicolumn{3}{|c|}{ LLRGLP } & \multicolumn{3}{|c|}{ CIRP } & \multicolumn{3}{|c|}{ EARTAP } \\
\hline & Coef. & $\mathrm{N}$ & R2 & Coef. & $\mathrm{N}$ & R2 & Coef. & $\mathrm{N}$ & $\mathrm{R} 2$ \\
\hline Tier 1/rwa & $\begin{array}{l}0.118^{* *} \\
(0.05)\end{array}$ & 970 & 0.27 & $\begin{array}{l}-0.573 * * * \\
(0.11)\end{array}$ & 970 & 0.23 & $\begin{array}{l}0.052 * * * \\
(0.01)\end{array}$ & 970 & 0.18 \\
\hline Tier 2/rwa & $\begin{array}{l}0.399 * * * \\
(0.09)\end{array}$ & 965 & 0.27 & $\begin{array}{l}-0.424 * \\
(0.23)\end{array}$ & 965 & 0.19 & $\begin{array}{l}-0.069 * * * \\
(0.02)\end{array}$ & 965 & 0.11 \\
\hline Total capital/rwa & $\begin{array}{l}0.208 * * * \\
(0.04)\end{array}$ & 1416 & 0.36 & $\begin{array}{l}-0.623 * * * \\
(0.08)\end{array}$ & 1416 & 0.30 & $\begin{array}{l}0.046 * * * \\
(0.01)\end{array}$ & 1416 & 0.15 \\
\hline Tier $1 /$ ta & $\begin{array}{l}0.504^{* * * *} \\
(0.04)\end{array}$ & 958 & 0.56 & $\begin{array}{l}-0.536^{* * *} \\
(0.12)\end{array}$ & 958 & 0.23 & $\begin{array}{l}0.09 * * * \\
(0.01)\end{array}$ & 958 & 0.30 \\
\hline Tier $2 /$ ta & $\begin{array}{l}0.824 * * * \\
(0.16)\end{array}$ & 946 & 0.39 & $\begin{array}{l}-0.366 \\
(0.35)\end{array}$ & 946 & 0.18 & $\begin{array}{l}-0.041 \\
(0.03)\end{array}$ & 946 & 0.07 \\
\hline Total capital/ta & $\begin{array}{l}0.487 * * * \\
(0.05)\end{array}$ & 1120 & 0.51 & $\begin{array}{l}-0.467 * * * \\
(0.11)\end{array}$ & 1120 & 0.25 & $\begin{array}{l}0.084 * * * \\
(0.01)\end{array}$ & 1120 & 0.29 \\
\hline Common equity/ta & $\begin{array}{l}0.226^{* * * *} \\
(0.05)\end{array}$ & 1877 & 0.33 & $\begin{array}{l}-0.642 * * * \\
(0.08)\end{array}$ & 1877 & 0.25 & $\begin{array}{l}0.097 * * * \\
(0.01)\end{array}$ & 1880 & 0.31 \\
\hline Tangible equity/ta & $\begin{array}{l}0.232 * * * \\
(0.06)\end{array}$ & 1877 & 0.33 & $\begin{array}{l}-0.713^{* * *} \\
(0.07)\end{array}$ & 1877 & 0.26 & $\begin{array}{l}0.1 * * * \\
(0.01)\end{array}$ & 1880 & 0.33 \\
\hline
\end{tabular}

Panel B: using a fixed-effect model

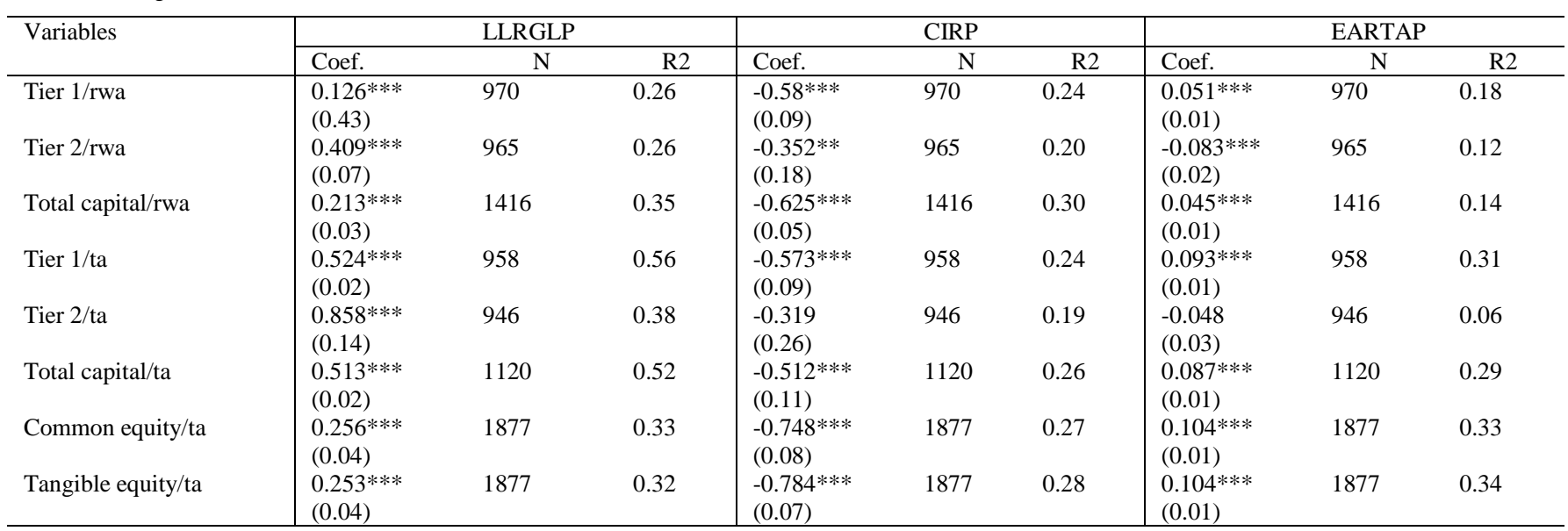

Panel C: using a random-effect model

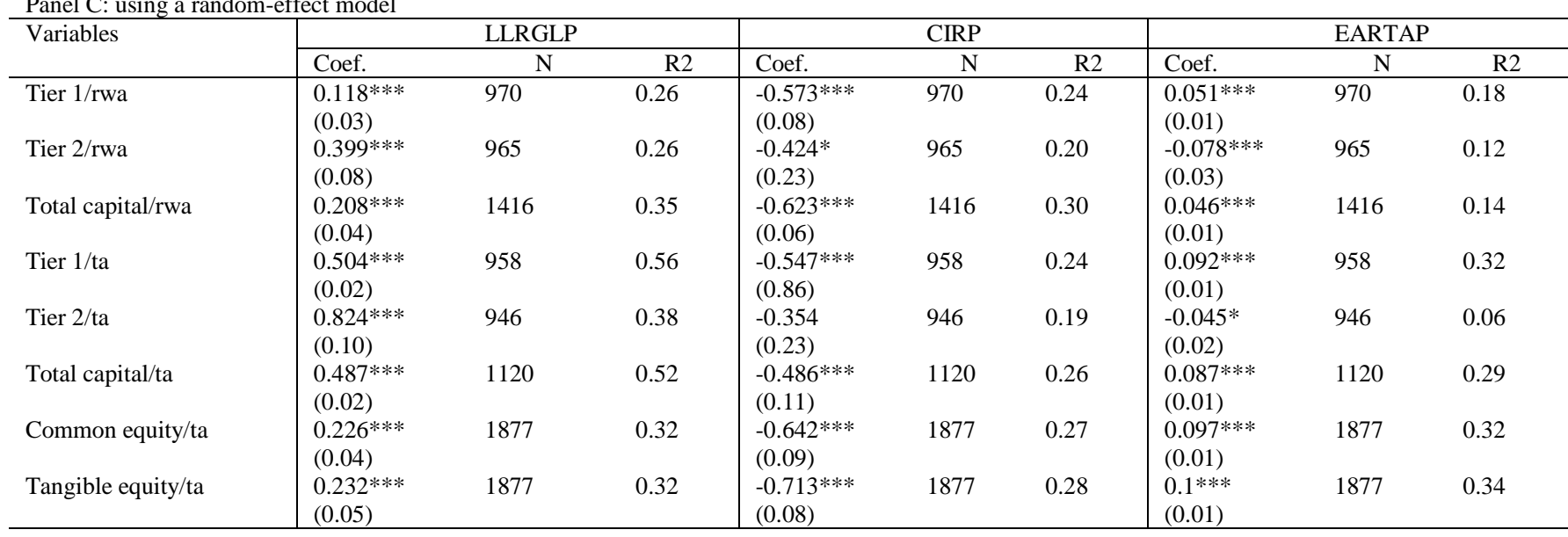

Panel D: using Fama-McBeth regressions

\begin{tabular}{|c|c|c|c|c|c|c|c|c|c|}
\hline \multirow[t]{2}{*}{ Variables } & \multicolumn{3}{|c|}{ LLRGLP } & \multicolumn{3}{|c|}{ CIRP } & \multicolumn{3}{|c|}{ EARTAP } \\
\hline & Coef. & $\mathrm{N}$ & $\mathrm{R} 2$ & Coef. & $\mathrm{N}$ & $\mathrm{R} 2$ & Coef. & $\mathrm{N}$ & $\mathrm{R} 2$ \\
\hline Tier 1/rwa & $\begin{array}{l}0.009 \\
(0.29)\end{array}$ & 970 & --- & $\begin{array}{l}-1.067 * * * \\
(0.27)\end{array}$ & 970 & --- & $\begin{array}{l}0.059 * * * \\
(0.04)\end{array}$ & 970 & $\begin{array}{ll}-- \\
\end{array}$ \\
\hline Tier 2/rwa & $\begin{array}{l}0.389 * * * \\
(0.40)\end{array}$ & 965 & --- & $\begin{array}{l}-0.066 \\
(0.92)\end{array}$ & 965 & --- & $\begin{array}{l}-0.062 * * * \\
(0.06)\end{array}$ & 965 & --- \\
\hline Total capital/rwa & $\begin{array}{l}0.211 * * * \\
(0.18)\end{array}$ & 1416 & --- & $\begin{array}{l}-0.659 * * * \\
(0.21)\end{array}$ & 1416 & --- & $\begin{array}{l}0.05 * * * \\
(0.03)\end{array}$ & 1416 & --- \\
\hline Tier $1 /$ ta & 0.111 & 958 & --- & $-1.052 * * *$ & 958 & --- & $0.113 * * *$ & 958 & --- \\
\hline
\end{tabular}




\begin{tabular}{|c|c|c|c|c|c|c|c|c|c|}
\hline & $(0.75)$ & & & (1.03) & & & $(0.09)$ & & \\
\hline Tier $2 /$ ta & $\begin{array}{l}0.886^{* * * *} \\
(0.97)\end{array}$ & 946 & --- & $\begin{array}{l}-0.202 \\
(1.32)\end{array}$ & 946 & --- & $\begin{array}{l}-0.102 \\
(0.26)\end{array}$ & 946 & --- \\
\hline Total capital/ta & $\begin{array}{l}0.462 * * * \\
(0.13)\end{array}$ & 1120 & --- & $\begin{array}{l}-0.738 * * * \\
(0.48)\end{array}$ & 1120 & --- & $\begin{array}{l}0.067 * * \\
(0.03)\end{array}$ & 1120 & --- \\
\hline Common equity/ta & $\begin{array}{l}0.212 * * * \\
(0.24)\end{array}$ & 1877 & --- & $\begin{array}{l}-0.809^{* * * *} \\
(0.40)\end{array}$ & 1877 & --- & $\begin{array}{l}0.112 * * * \\
(0.04)\end{array}$ & 1877 & -- \\
\hline Tangible equity/ta & $\begin{array}{l}0.22 * * * \\
(0.23)\end{array}$ & 1877 & --- & $\begin{array}{l}-0.836^{* * * *} \\
(0.37)\end{array}$ & 1877 & --- & $\begin{array}{l}0.112 * * * \\
(0.03)\end{array}$ & 1877 & --- \\
\hline
\end{tabular}

(Continued)

Notes: See Appendix A.1 for the variables' definitions. In Panel A, we employ a bootstrapped model with heteroscedasticityconsistent standard errors. In Panel B, we use a fixed-effect model. In Panel C, we use a random-effect model. In Panel D, we use a Fama-McBeth estimation technique. The dependent variables are the bank loan loss reserves to gross loans (LLRGLP), the bank cost to income ratio (CIRP) and the bank earnings to assets (EARTAP). Standard errors are clustered at the bank level and reported in parentheses below their coefficient estimates.

* Statistical significance at the $10 \%$ level.

** Statistical significance at the $5 \%$ level.

*** Statistical significance at the $1 \%$ level. 


\section{Appendix A}

\section{A.1.Variable definitions and data sources}

\begin{tabular}{|c|c|c|}
\hline Variable & Definition & Data Sources \\
\hline $\begin{array}{l}\text { Dependent variables } \\
\text { 1. Risk model } \\
\text { Loan loss/gross loans (LLRGLP) }\end{array}$ & Bank reserves for loan loss divided by gross loans times 100 . & Bankscope \\
\hline \multicolumn{2}{|l|}{ (NPLGLP) } & Bankscope \\
\hline \multicolumn{3}{|l|}{ 2. Efficiency model } \\
\hline Net interest margin (NIMP) & $\begin{array}{l}\text { Bank interest income minus bank interest expenses as a percentage of earning } \\
\text { assets. }\end{array}$ & Bankscope \\
\hline $\begin{array}{l}\text { 3. Profitability model } \\
\text { Earnings/ta (EARTAP) }\end{array}$ & $\begin{array}{l}\text { Bank interest income minus bank interest expenses as a percentage of total } \\
\text { assets. }\end{array}$ & $\begin{array}{l}\text { Authors' calculations } \\
\text { based on Bankscope }\end{array}$ \\
\hline Earnings/gross loans (EARGLP) & $\begin{array}{l}\text { Bank interest income minus bank interest expenses as a percentage of gross } \\
\text { loans. }\end{array}$ & $\begin{array}{l}\text { Authors' calculations } \\
\text { based on Bankscope }\end{array}$ \\
\hline \multicolumn{3}{|l|}{ Independent variables } \\
\hline $\begin{array}{l}\text { 1. Capital requirements } \\
\text { Tier } 1 / \text { rwa }\end{array}$ & $\begin{array}{l}\text { This measure of capital adequacy measures Tier } 1 \text { capital divided by risk- } \\
\text { weighted assets computed under the Basel rules. Banks must maintain } \\
\text { minimum Tier } 1 \text { capital of at least } 4 \% \text {. }\end{array}$ & Bankscope \\
\hline Tier $2 /$ rwa & $\begin{array}{l}\text { This measure of capital adequacy measures Tier } 2 \text { capital divided by risk- } \\
\text { weighted assets computed under the Basel rules. }\end{array}$ & $\begin{array}{l}\text { Authors' calculations } \\
\text { based on Bankscope }\end{array}$ \\
\hline Total capital/rwa & $\begin{array}{l}\text { This ratio is the capital adequacy ratio. It is the sum of bank Tier } 1 \text { plus Tier } \\
2 \text { capital as a percentage of risk-weighted assets. This ratio must be } \\
\text { maintained at a level of at least } 8 \% \text { under the Basel II rules. }\end{array}$ & Bankscope \\
\hline Tier $1 / \mathrm{ta}$ & $\begin{array}{l}\text { This measure of capital adequacy measures Tier } 1 \text { capital divided by total } \\
\text { assets. }\end{array}$ & $\begin{array}{l}\text { Authors' calculations } \\
\text { based on Bankscope }\end{array}$ \\
\hline Tier 2/ta & $\begin{array}{l}\text { This measure of capital adequacy measures Tier } 2 \text { capital divided by total } \\
\text { assets. }\end{array}$ & $\begin{array}{l}\text { Authors' calculations } \\
\text { based on Bankscope }\end{array}$ \\
\hline Total capital/ta & This measure is bank Tier 1 plus Tier 2 capital divided by total assets. & $\begin{array}{l}\text { Authors' calculations } \\
\text { based on Bankscope }\end{array}$ \\
\hline Common equity/ta & $\begin{array}{l}\text { Bank common equity includes common shares and premium, retained } \\
\text { earnings, reserves for general banking risks and statutory reserves divided by } \\
\text { total assets. }\end{array}$ & $\begin{array}{l}\text { Authors' calculations } \\
\text { based on Bankscope }\end{array}$ \\
\hline Tangible equity/ta & $\begin{array}{l}\text { Bank tangible equity divided by total assets. This measure removes goodwill } \\
\text { and any other intangible assets from both the equity and the asset side of the } \\
\text { bank balance sheet. }\end{array}$ & $\begin{array}{l}\text { Authors' calculations } \\
\text { based on Bankscope }\end{array}$ \\
\hline \multicolumn{3}{|l|}{ 2. Bank control variables } \\
\hline Net loans/ta & The share of net loans as a percentage of bank total assets. & $\begin{array}{l}\text { Authors' calculations } \\
\text { based on Bankscope }\end{array}$ \\
\hline Growth assets & $\begin{array}{l}\text { The current year growth of bank total assets compared with the previous } \\
\text { year's total assets. }\end{array}$ & Bankscope \\
\hline Income diversity & $\begin{array}{l}\text { 1-[(net interest income-other operating income)/(operating income })] \text {. } \\
\text { Higher values mean more diversified activities. }\end{array}$ & $\begin{array}{l}\text { Authors' calculations } \\
\text { based on Bankscope }\end{array}$ \\
\hline Size & The natural logarithm of total assets. & $\begin{array}{l}\text { Authors' calculations } \\
\text { based on Bankscope }\end{array}$ \\
\hline \multicolumn{3}{|l|}{ 3. Country control variables } \\
\hline World Governance Index & $\begin{array}{l}\text { The World Governance Index includes six governance dimensions: (1) voice } \\
\text { and accountability, (2) political stability and absence of violence, (3) } \\
\text { government effectiveness, (4) regulatory quality, (5) rule of law and (6) } \\
\text { control of corruption. }\end{array}$ & $\begin{array}{l}\text { Kaufmann et al. } \\
\text { (2006); World Bank } \\
\text { (2013) }\end{array}$ \\
\hline Arab Spring (AS_1) & $\begin{array}{l}\text { A dummy variable that takes the value of } 1 \text { for countries that face } \\
\text { revolutions and political changes and } 0 \text { otherwise. }\end{array}$ & Ghosh (2015) \\
\hline
\end{tabular}




\section{Quantile plots}
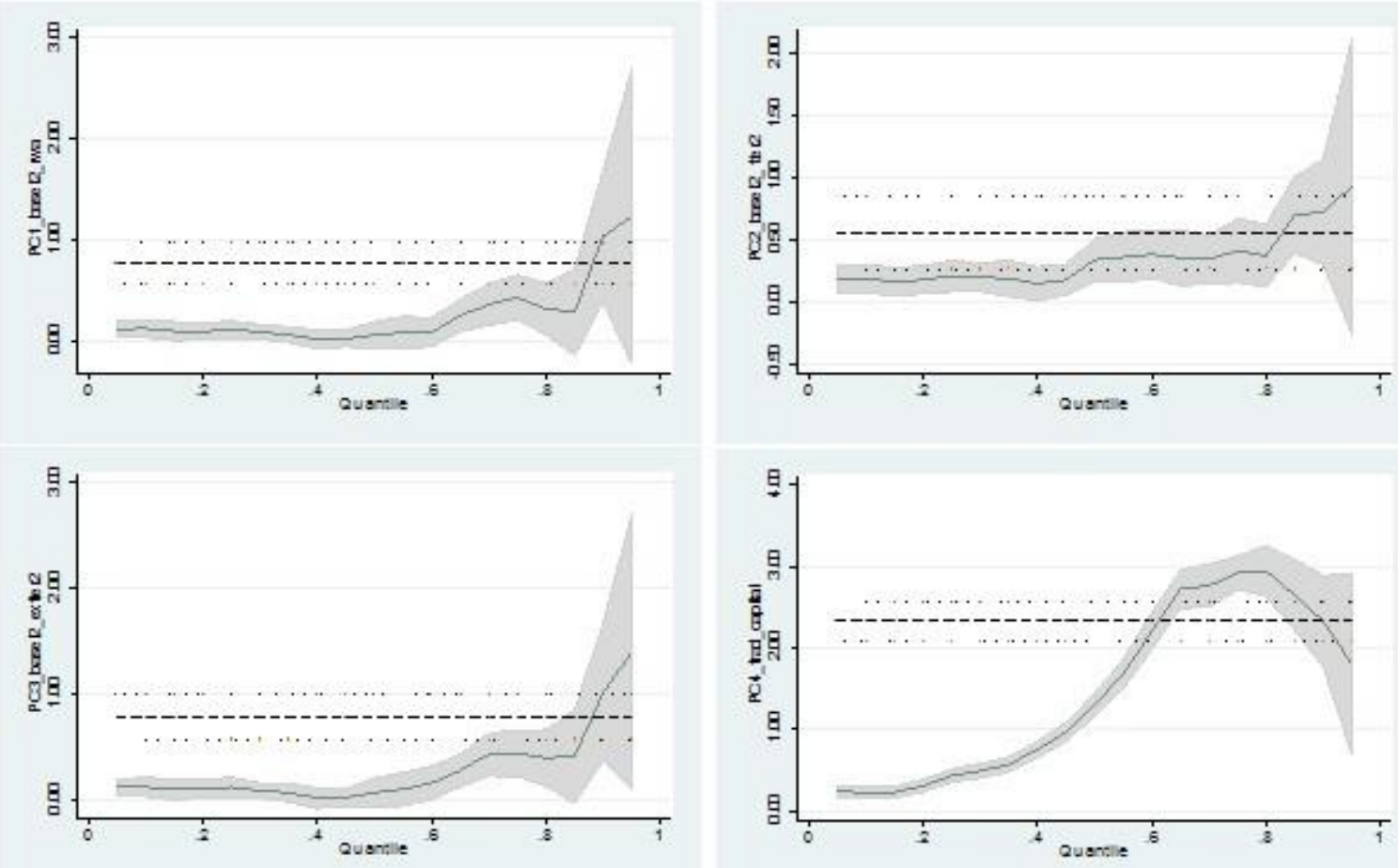

Fig. 1. Capital components and bank risk
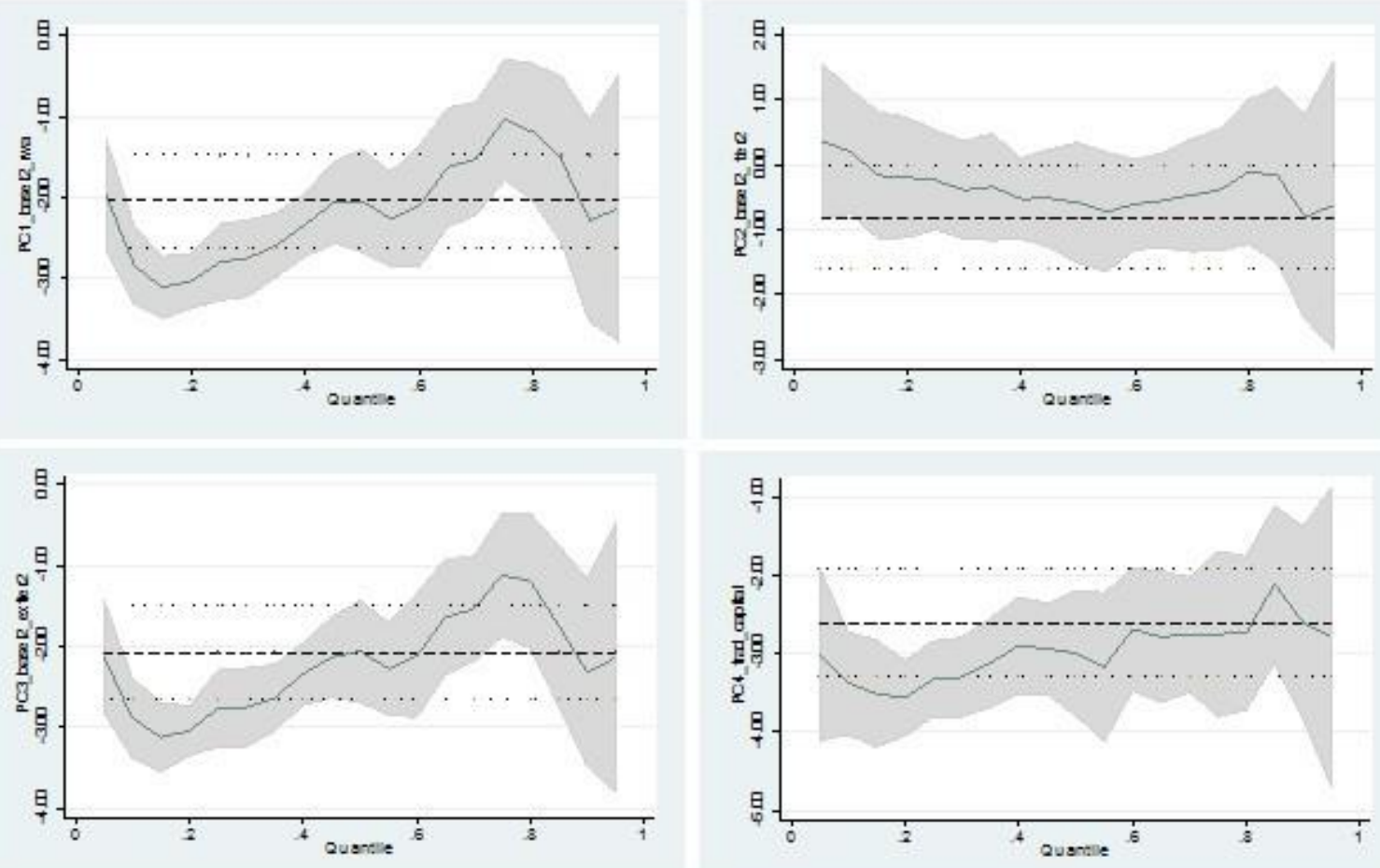

Fig. 2. Capital components and bank efficiency 

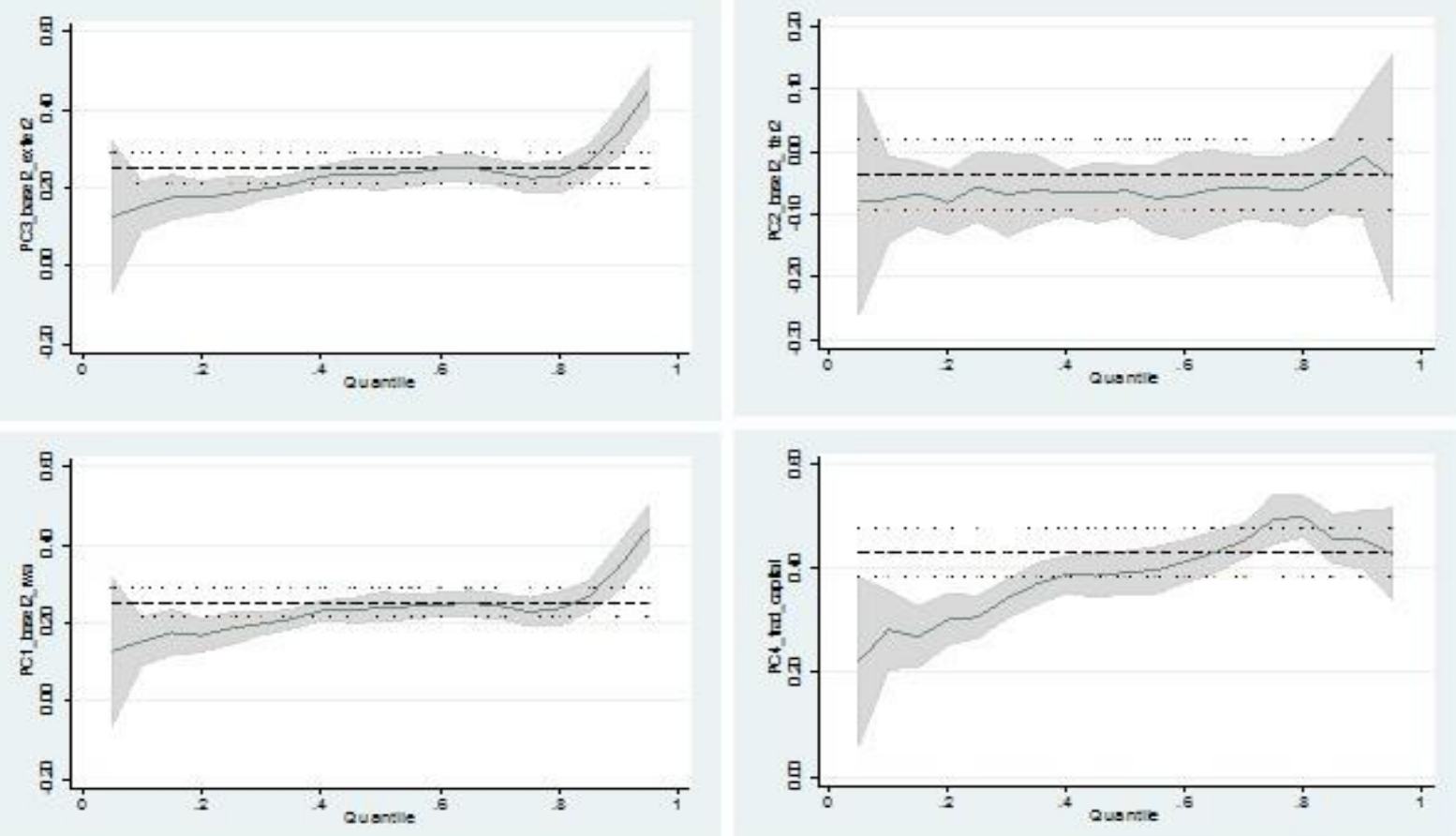

Fig. 3. Capital components and bank profitability 